\title{
The Roles of p53 in Mitochondrial Dynamics and Cancer Metabolism: The Pendulum between Survival and Death in Breast Cancer?
}

\author{
David E. Moulder ${ }^{1}$, Diana Hatoum ${ }^{1}$, Enoch Tay ${ }^{2}$, Yiguang Lin ${ }^{1, *}$ (1) \\ and Eileen M. McGowan ${ }^{3, *}$ (i) \\ 1 School of Life Sciences, University of Technology Sydney, 15 Broadway, Ultimo NSW 2007, Australia; \\ d.moulder@garvan.org.au (D.E.M.); diana.hatoum@student.uts.edu.au (D.H.) \\ 2 Viral Hepatitis Pathogenesis Group, The Westmead Institute for Medical Research, University of Sydney, \\ 176 Hawkesbury Road, Westmead NSW 2145, Australia; enoch.tay@sydney.edu.au \\ 3 Central Laboratory, The First Affiliated Hospital of Guangdong Pharmaceutical University, \\ Guangzhou 510080, China \\ * Correspondence: Eileen.mcgowan@uts.edu.au (E.M.M.); Yiguang.lin@uts.edu.au (Y.L.); \\ Tel.: +61-4-0581-4048 (E.M.M.); +61-2-9514-2223 (Y.L.)
}

Received: 3 May 2018; Accepted: 5 June 2018; Published: 8 June 2018

\begin{abstract}
Cancer research has been heavily geared towards genomic events in the development and progression of cancer. In contrast, metabolic regulation, such as aberrant metabolism in cancer, is poorly understood. Alteration in cellular metabolism was once regarded simply as a consequence of cancer rather than as playing a primary role in cancer promotion and maintenance. Resurgence of cancer metabolism research has identified critical metabolic reprogramming events within biosynthetic and bioenergetic pathways needed to fulfill the requirements of cancer cell growth and maintenance. The tumor suppressor protein p53 is emerging as a key regulator of metabolic processes and metabolic reprogramming in cancer cells-balancing the pendulum between cell death and survival. This review provides an overview of the classical and emerging non-classical tumor suppressor roles of p53 in regulating mitochondrial dynamics: mitochondrial engagement in cell death processes in the prevention of cancer. On the other hand, we discuss p53 as a key metabolic switch in cellular function and survival. The focus is then on the conceivable roles of p53 in breast cancer metabolism. Understanding the metabolic functions of p53 within breast cancer metabolism will, in due course, reveal critical metabolic hotspots that cancers advantageously re-engineer for sustenance. Illustration of these events will pave the way for finding novel therapeutics that target cancer metabolism and serve to overcome the breast cancer burden.
\end{abstract}

Keywords: breast cancer; p53; tumor suppressor protein; p14ARF; metabolism; mitochondria

\section{Introduction}

Nicknamed the "Guardian of the Genome," p53 (encoded by the TP53 gene) is believably the most extensively studied and most multifaceted tumor suppressor protein identified to date [1-3]. The role of p53 extends well beyond its role as a tumor suppressor; it is emerging as an important regulator of metabolic homeostasis, pivotal in most major cellular processes [1,4-8]. In the breast p53 plays a fundamental role in cell homeostasis: maintaining metabolic homeostasis during pregnancy, providing a protective role against latent breast cancer [9], and its more classical roles of protecting the genome, DNA repair, and/or programmed cell death [10]. Critical mutations in the TP53 gene are common in most cancers and major contributors to cancer progression. In contrast, the majority of breast cancers harbor wild-type p53 (wt-p53), though in most cases the protein is non-functional, 
in part due to loss of upstream regulators in the p53 pathway [11]. Classical thinking supports that reinstating the p53 pathway may be one avenue of more efficacious breast cancer treatment through p53 activation of programmed cell death pathways. This concept may be flawed due to the poorly understood role of p53 in cellular metabolism, which is currently being widely revisited.

Originally, altered metabolism was deemed to be merely a byproduct of cancer, rather than being considered as playing an intricate role in its support and maintenance. In the last decade, however, the resurgence of cancer metabolism research has increased exponentially. Cancer metabolism is now being viewed as a series of critical metabolic reprogramming events within biosynthetic and bioenergetic pathways, needed to fulfil the requirements of cancer cell growth and maintenance [1,12-14]. Renewed focus on cancer metabolism has identified the tumor suppressor protein, p53, as a key regulator of metabolic processes and metabolic programming [1,15-17].

This review firstly provides a brief understanding of ongoing problems with breast cancer therapy. Next, we provide an overview of the classical and non-classical roles of p53 focusing in on the emerging, critical roles of p53 in metabolic reprogramming. On one hand, p53 engages in mitochondrial cell death processes in the prevention and treatment of cancer, and on the other hand it plays an important role in cell survival and function, hence 'balancing the pendulum between cell death and survival'. Further, we bring back the discussion to how these p53-reprogramming events may be important in cell survival and provide new avenues for breast cancer therapies.

\subsection{Overview of Breast Cancer}

Breast cancer is the most commonly diagnosed cancer and cause of cancer deaths among women worldwide: an estimated 1.7 million cases were diagnosed in 2014, accounting for $25 \%$ of all cancers in women [18]. One in eight women will develop breast cancer in their lifetime $[19,20]$. Upon diagnosis, breast cancers are categorized into subtypes that are defined based on their stage of progression, level of invasiveness, and hormonal receptor status [21-23]. There are three distinct classes of hormone receptor profiles that are typically overexpressed and highly dysregulated in breast cancer. These include: (1) the estrogen receptor (ER $\alpha)$ /progesterone receptor (PR); (2) human epidermal growth factor receptor 2 (HER2); and (3) triple-negative breast cancers (TNBC) that do not express any of these three receptors [21-23]. The prevalence of each of these subclasses and their typical treatments are summarized in Table 1. Common treatment regimes for breast cancer include surgical ablation, adjuvant or neoadjuvant chemotherapy, radiotherapy, and endocrine therapy, with the therapeutic strategy dependent on the stage and type of cancer [24]. Radiotherapy and chemotherapy induce DNA damage, inducing cell cycle arrest and apoptosis [25-28]. Endocrine therapy, including Tamoxifen and Fulvestrant, blocks the ER $\alpha$ receptor, which in turn represses aberrant estrogen signaling [21]. Similarly, targeted therapies like Trastuzumab target the overexpression of HER2 [21,29], while aromatase inhibitors inhibit the synthesis of estrogen $[21,30]$.

Table 1. Major breast cancer receptor sub-types and standard therapies.

\begin{tabular}{cccc}
\hline Receptor Status [21,31] & Prevalence (\%) & Endogenous Ligand & Standard Therapy Type \\
\hline ER $\alpha+/$ PR + & $70-80 \%$ & Estradiol/Progesterone & Endocrine Therapy \\
HER2+ & $15-20 \%$ & EGF, TGF- $\alpha$ & HER2-targeted Therapy \\
TNBC & $15 \%$ & - & Chemotherapy/Radiotherapy \\
\hline
\end{tabular}

Note: ER, PR, and HER2 receptors are listed alongside their associated prevalence in breast cancers. TNBC refers to an absence of all three receptor types; this tumor type is notoriously difficult to treat [32]. The typical endogenous binding ligands and treatment type are also shown with the respective receptor profile.

\subsection{Breast Cancer Treatment Resistance and Recurrence}

Current therapeutics, used alone or in combination, have been successful in the treatment of breast cancer, with favorable increases in overall survival in recent decades [33]. Unfortunately, a major challenge involves a large proportion of breast cancer patients developing resistance to these 
treatments ( $50 \%$ of ER $\alpha+/ \mathrm{PR}+$ breast cancer, which comprises $70-80 \%$ of all breast cancers, inevitably recur) $[21,34,35]$. Resistance leads to the recurrence of more aggressive secondary tumors [36,37], stressing the need for further research into the fundamental cellular mechanisms that promote breast cancer tumorigenesis, resistance, and recurrence. More recently, targeting dysregulated metabolism is a reemerging area of cancer research. Metabolic reprogramming is now being recognized as a cancer hallmark.

To date, breast cancer research has been heavily focused on exploring the contributions of hyperactive growth and hormone receptor signaling, inherited and sporadic gene mutations, oncogene amplification, loss of tumor suppressor proteins, and cancer heterogeneity in the development and progression of breast cancer. For instance, mutations in the breast cancer genes BRCA1 and BRCA2 as well as the TP53 gene have all been well characterized in breast cancer [38-41]. Aberrations in the P13K/AKT signaling pathway, which regulates the cell cycle and cell proliferation, are also well documented [42]. In contrast, aberrant metabolism, as a contributing factor to the onset, progression, and maintenance of breast cancer, is poorly understood.

In contrast to most cancers, mutations in the TP53 gene are only present in $20-30 \%$ of all breast cancers, suggesting that p53 function is compromised [43,44] (discussed in Section 4). Alongside its well-recognized role as a tumor suppressor, p53 has emerged as a major regulator of metabolic processes and metabolic programming and is intrinsically linked with mitochondria and mitochondrial dynamics associated with cell survival $[1,15-17,45]$. Further, more and more evidence is emerging to suggest an association between drug resistance and dysregulated cellular metabolism [46]. In the normal breast, during pregnancy p53 plays a key role in the reprogramming of breast cell function and is strongly associated with protection against latent breast cancer. However, it is also associated with the seeding of latent breast cancer, as reviewed in [9].

What key knowledge are we missing regarding the role p53 plays as the 'guardian of metabolism' that will help us understand breast cancer development, survival, resistance to treatment, and impact on breast cancer recurrence?

\section{The Multifaceted Tumor Suppressor Roles of p53}

The p53 protein is a transcriptional regulator that is stabilized within the nucleus upon DNA damage or oncogenic signaling. p53 regulates genes involved in cell cycle arrest, cell death (apoptosis), DNA repair, and senescence to prevent tumor development and growth [3,5,47-51]. p53 also localizes to the cytoplasm and the mitochondria, where it can regulate cytoplasmic cellular functions including apoptosis. Non-canonical functions of p53, including necrosis [52], autophagy [53], and the less well-known functions of p53, necroptosis (inflammatory programmed cell death) [54] and ferroptosis (iron- and lipid-mediated cell death), have all been shown to be p53-activated specialized forms of mitochondria-programmed cell death processes [5,50,51]. Critical mutations in p53 can prevent its anti-tumor functions and/or enhance oncogenicity $[55,56]$. All these p53 functions, which are briefly discussed as part of this review, are clearly directed towards the physiology of removing abnormal cells and prevention of tumorigenesis. Additional less characterized p53-associated processes that do not necessarily lead to cell death include autophagy, senescence, differentiation, and dormancy. In recent years, mounting evidence has also implicated p53 as a central player in the regulation of cellular energy metabolism [1,10,15-17], alongside potential roles in the regulation of mitochondrial dynamics, beyond cell death [57-59]. Homeostasis regulation of the mitochondrial DNA involves both p53-nuclear transcriptional target genes, whose products translocate to the mitochondria or non-nuclear direct cytoplasmic effects of the p53 protein.

\subsection{Canonical and Non-Canonical Functions of p53 in Cancer Protection}

Much of the p53 literature is directed towards the well-characterized canonical tumor suppressor protective roles of p53, which are typically impaired upon mutation or deletion, leading to the production of many of its oncogenic forms $[15,39,60]$. Oncogenic p53 mutations, resulting in change 
or loss of function, are found in approximately $50 \%$ of all human cancers, making it one of the most frequently mutated proteins in cancer [39,61]. From its widespread transcriptional factor activity, p53 has the ability to activate the expression of genes associated with cell cycle arrest, cell death, DNA repair, and cell abeyance, which occurs in response to a range of cellular stress signals that post-translationally activate p53 (Figure 1) [48,53,62,63].

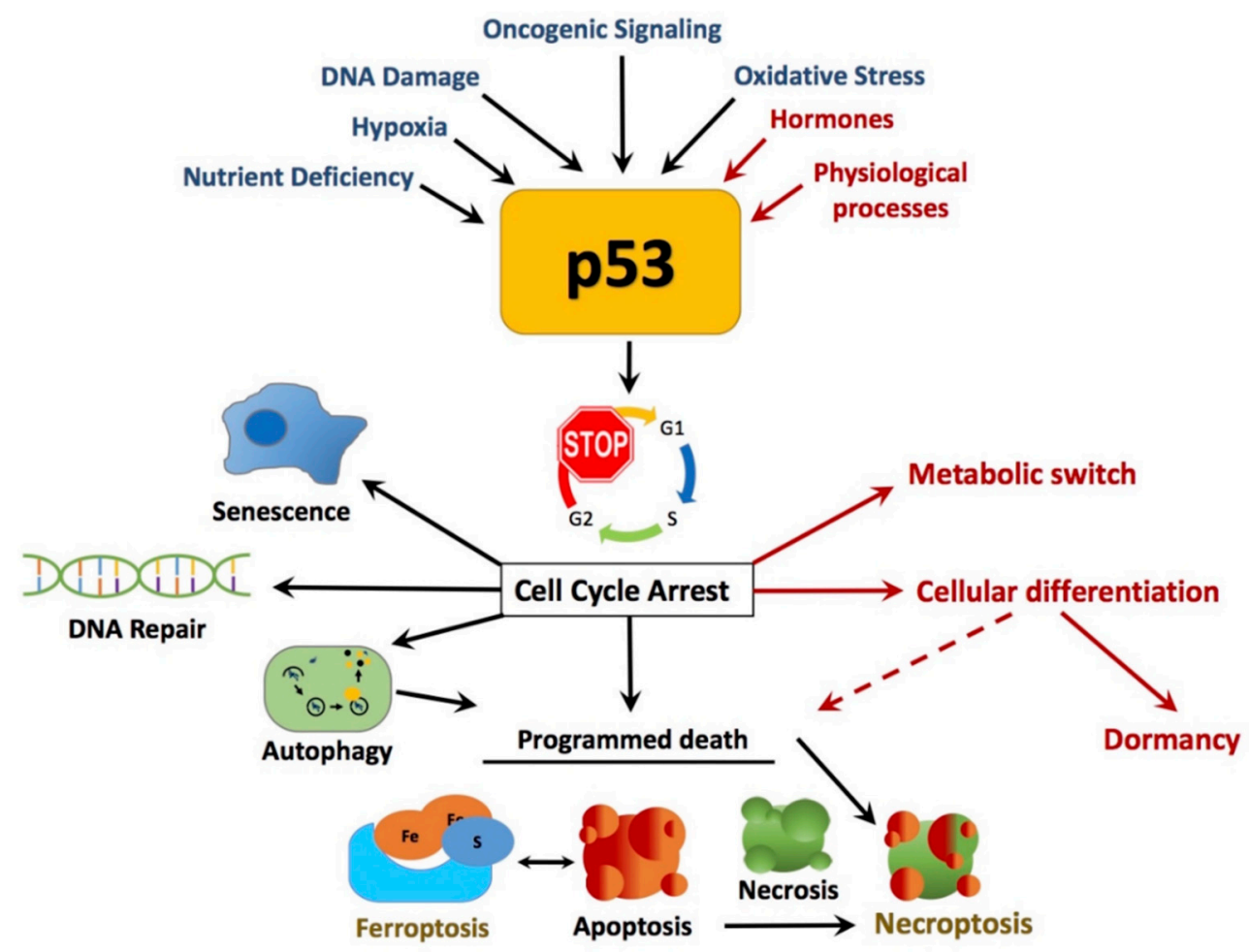

Figure 1. p53 canonical and non-canonical tumor suppressor roles of p53. p53 is activated by a range of cellular stress signals. These activators of p53 include nutrient stress, hypoxic conditions, activation of oncogenes, DNA damage, and oxidative stress from reactive oxygen species (ROS) and, as a result, increase the activity of p53. Classical or canonical responses of p53 include, transcriptionally and translationally, cell cycle arrest and repair damage to DNA, which place the cell in a state of senescence or induce apoptosis. Non-canonical, controlled programmed cell death roles include autophagy pathways, necrosis, necroptosis, and ferroptosis [5,48,50-53,62-64]. Normal physiological processes such as hormone activation can also lead to p53-induced cell cycle arrest and p53 acts as a switch in metabolic process involved in differentiation, redirecting specialized cell function [9].

\subsubsection{DNA Damage}

One of the early identified major functions of p53 is to prevent accumulation of damaged DNA to potentiate genomic stability, thus inhibiting tumorigenesis [65]. This is achieved by temporarily inhibiting cell proliferation to allow for the repair of DNA damage prior to DNA synthesis, or, in the case of irreparable DNA damage, initiate programmed cell death to remove mutated cells. The ability of p53 to initiate DNA repair is conventionally through stimulating the transcription of the downstream cell cycle inhibitor p21 and hence triggering DNA damage repair mechanisms [66-69]. Unsurprisingly, the p21 regulatory checkpoint machinery is commonly overridden in cancer [68]. In response to cell cycle arrest, DNA repair mechanisms are frequently upregulated to repair the respective DNA damage before the cell is permitted to re-enter the cell cycle. Specifically, these include the confirmed roles of p53 in transcriptionally coordinating genes, allied to the nucleotide excision and base excision repair pathways $[68,70,71]$. These repair pathways mediated by p53 carry out DNA repair functions including 
single-stranded break repair and the repair of other DNA lesions within the genome to prevent genomic instability. Paradoxically, it is mutations in the p53 gene itself that lead to tumor formation.

\subsubsection{Apoptosis}

One of the most well-recognized canonical p53 programmed cell death pathways is apoptosis. Nuclear p53 regulates genes associated with apoptosis in response to cellular stress signals via the classical mitochondrial apoptotic pathway [49]. The primary mechanism by which p53 induces apoptosis is transcriptional regulation of the pro-apoptotic proteins NOXA and p53-upegulated modulator of apoptosis [72-74]. An additional mechanism by which p53 induces apoptosis is direct translocation to the mitochondria, activating the mitochondrial apoptotic regulator BAX [75]. This implies that p53 mediates apoptosis both by transcriptional and post-translational mechanisms. However, the question of how p53 activation induces apoptosis outside of its other well-known cellular fate functions remains unclear. One proposal highlights that p53 may need to reach an "apoptotic threshold" that overrides other functions to correspondingly promote apoptosis [49]. Other studies suggest that the strength, duration of activation, sub-cellular location, and environmental co-factors of p53 play key roles in determining the downstream outcomes of p53 activation $[48,49,76]$.

\subsubsection{Necrosis}

Necrosis was once regarded as uncontrolled or 'accidental' cell death. This idea has been superseded; necrosis is now regarded as a process of irreversible programmed cell death where apoptosis has failed and can also be triggered by $\mathrm{p} 53[52,64,77]$. Necrosis is a caspase-independent pathway requiring receptor interaction protein kinases 1 and 3 (RIP1 and 3) and can be mediated by $53[54,78]$. Subsequently, this action directly or indirectly affects mitochondria through NADPH oxidase-derived ROS. The terms of necrosis have extended to include programmed necrosis, regulated necrosis and necroptosis. Necroptosis is a relatively new concept, which is a combination of necrosis and apoptosis-mediated p53 cell death and contributes to immune system regulation, contributing to managing cells during inflammation, tissue injury, and other organismal stresses such as pathogen infection $[78,79]$.

\subsubsection{Autophagy}

The definition of autophagy, from an ancient Greek word, is 'self-devouring'. Autophagy is an evolutionarily conserved, genetically mapped process that forms the "recycling facility" of the cell. This is a normal process in the cell to maintain homeostasis through programmed protein degradation and turnover of organelles within the cell. This allows the cell to degrade organelles and proteins to functional building units to fuel bioenergetic and biosynthetic processes [80]; alternatively, cancer cells can undergo autophagy as a mechanism of cell death [81]. This catabolic pathway, involved in both normal cell physiology and cancer pathophysiology, is modulated by p53-dependent mechanisms, which is dependent on p53 cellular localization [82-85]. Within this context, p53 is seen to have a dual/paradoxical role in regulating autophagy. On the one hand, the nuclear p53 function has been shown to transcriptionally activate pro-autophagy genes; conversely, its cytoplasmic role shows evidence of negatively regulating autophagy $[82,83,85]$. Therefore, the cellular context and environment determines the role of p53 in autophagy signaling pathways. Autophagy is also important in selective degradation of mitochondria (mitophagy) in mitochondria quality control [86]. In cancer, autophagy has a controversial role, and is associated with interventions to both stimulate and inhibit cancer, as debated in the recent review by Thorburn [87].

\subsubsection{Dormancy}

Perhaps one of the most under-researched roles of p53 is dormancy. It has been suggested that dormancy may be viewed as a natural byproduct of evolutionary mechanisms, where dormant cells are present in both healthy individuals and survivors of cancer [88]. The dormant cell minimizes 
energy expenditure to survive in adverse conditions. Mitochondria undergo active to deactivate transition; however, the exact mechanism of this transition is unclear [89]. In breast cancer the concept of cancer dormancy is particularly relevant given that most breast cancers are seeded early in life and yet only manifest in later years. Many years after seemingly successful breast cancer treatment, $20-50 \%$ of breast cancers recur, believed to reemerge from remnant dormant cells from the original tumor $[90,91]$. How this is achieved is unknown. Autophagy has been suggested as one of the key processes to long-term cancer survival, allowing stressed cells to remain dormant yet viable in order to survive and eventually regrow and relapse [91,92]. An additional theory is that tumor dormancy results from tumor cells reaching a differentiated state [91]. In our laboratory we have shown that p53 can induce a dormant state in breast cancer cells, which has features of differentiation or senescent-like morphology $[59,93,94]$. We also demonstrated that these breast cancer cells can remain viable for many weeks in cell culture after p53-induced cell cycle arrest and eventually multiply by a process of endoreplication or nuclear replication without mitosis [93]. Endoreplication may be one method by which breast cancer cells escape dormancy and become more aggressive.

\subsubsection{Cellular Senescence or Quiescence or Dormancy}

p53 is a decision maker in cellular senescence, quiescence, or dormancy. Senescence is defined as a state of irreversible cell cycle arrest in which cells display an inability to proliferate or respond to growth factors [95-98]. In vivo studies highlight the pivotal role that p53-induced senescence plays in tumor suppression $[95,98]$. Quiescence, a prolonged cell cycle arrest and attenuated cellular activity at the G0-G1 phase, is also mediated by p53 $[99,100]$. Alternatively, dormancy is not unheard of in terms of breast cancer recurrence, with $20-50 \%$ of all breast cancers recurring from years to decades post treatment $[35,90]$. A common attempt to explain dormancy arises from models of both senescence and quiescence, both mediated by p53. However, understanding the paradox of how these potentially overlapping, and supposedly anti-tumorigenic functions facilitate dormancy and lead to recurrence remains incomplete [91]. One potentially unidentified area to be investigated involves the effects of p53 within cancer metabolism throughout and leading up to the point of recurrence.

\subsubsection{Ferroptosis}

Only discovered in 2012, ferroptosis is a novel non-apoptotic form of cell death, characterized by lethal iron-dependent accumulation of lipid ROS, in a caspase-independent manner [101]. Morphologically, cells undergoing ferroptosis cell death are distinguished by small mitochondria with condensed membrane density. Dixon and colleagues discovered that ferroptosis action can be blocked or reversed by ferrostatin (Fer-1) in cancer cells [101]. Fer-1 has been shown to reverse ferroptosis action through increasing the mitochondrial membrane potential and decreasing ROS accumulation [102]. To investigate the process of ferroptosis, $\mathrm{Gu}$ and colleagues generated a mouse model (named p53) that was unable to undergo p53-dependent cell cycle arrest, apoptosis and senescence, but was still able to regulate p53-dependent changes in energy metabolism and ROS production [103]. This suggested that the p53 associated energy metabolism and ROS functions were disconnected from conventional cell cycle arrest and death mechanisms. Specific p53 target genes have been identified as important in p53-directed ferroptosis including solute carrier family 7 member 11 , a cysteine-glutamate exchanger, glutamase 2 (GLS2), prostaglandin-endoperoxide synthase 2, and spermidine/spermine N1-acetytransferase1 [5]. This unique form of cell death is implicated in multiple disease states including cancer [50].

In summary, mitochondria are core powerhouses for metabolic reactions that drive cellular reprogramming through diverse pathways and mechanisms. Classical roads in p53 tumor suppression lead to mitochondrial de-regulation or inactivity, whether it be for cell destruction or temporary/permanent inactivation, respectively. Alternatively, p53 is linked to the quality control mechanisms of the mitochondria and its genome, with projected roles in the organelle fusion-fission process (discussed in Section 3.4) and supporting cell survival. 


\section{Emerging Roles of p53 in Cancer Metabolism}

Alteration in cancer cell metabolism is now considered a hallmark of cancer, whereby the metabolic signatures of cancer cells are distinctly different from normal tissue [12,14,104-106]. These observed differences reflect metabolic changes that strategically fuel the requirements for tumor development. p53 has emerging roles in counteracting the changes that occur in the metabolism of cancer cells through regulation of several metabolic targets [1,10,15-17].

\subsection{Metabolic Reprogramming for Cellular Proliferation}

Cellular division requires an adequate biomass to produce two identical daughter cells. This growth imposes a metabolic burden, requiring the cell to increase its energy supply to meet the requirements for proliferation [13,107]. In cancer, the normal regulatory checkpoints within cellular division are lost, permitting the cell to unceasingly proliferate [108]. Re-engineering of fundamental metabolic pathways and nutrient uptake mechanisms often occurs to support this uncontrolled proliferation. This 'metabolic switch' or metabolic reprogramming provides inherent growth advantages in fulfilling the requirements of cancer cells [12-14,104]. These alterations include: (1) restructuring the key metabolic pathways involved in glucose catabolism; (2) maintaining the nutrient uptake mechanisms to meet metabolic demands; and (3) quickly replenishing anabolic substrates needed for biosynthetic pathways (anaplerosis) such as nucleotide, protein, and lipid synthesis $[12-14,104]$. These observations stem from a fundamental metabolic switch, formally known as the Warburg effect (described in Section 3.2), whereby cancer cells show high dependence on glycolysis and attenuated mitochondrial respiration $[106,109,110]$. To provide this demand for glucose, cancer cells typically overexpress glucose transporters, supporting glucose flux [111,112]. This reliance on glycolysis, however, is not sufficient for cellular replication. Instead, principal anabolic substrates found within and entering the tricarboxylic acid (TCA) cycle serve as hybrid intermediates, forming the building blocks needed for proliferation [113]. One of these includes the reliance of cancer cells on glutamine, which is converted to $\alpha$-ketoglutarate within the TCA cycle [113]. Furthermore, cancer proliferation requires increased fatty acid synthesis for membranes and lipid molecules. As such, controlling fatty acid synthesis has been proposed as a potential therapeutic strategy $[114,115]$. Collectively, these metabolic strategies are employed to support cancer growth and maintenance and, without such adaptive strategies, cancer cells will likely undergo apoptosis.

Now considered a hallmark of cancer, aberrant metabolism in cancer is re-emerging as an area of intense research. As such, rectifying this aberrant metabolism is an appealing potential cancer treatment. It is expected that intervention leading to interference with cancer cell metabolism would form a successful treatment strategy. Before the development of a treatment strategy based on metabolism intervention, a deep understanding of how cancer metabolism is reprogrammed and regulated is needed. Recently, the tumor suppressor p53 has been implicated as a master regulator of metabolism $[1,10,15-17]$; therefore, understanding the role of p53 in the regulation of cellular metabolic processes may provide further avenues for the future treatment of cancer.

\subsection{The Warburg/Weinhouse Debate}

The Metabolic Switch. The concept of cancer metabolic switching from oxidative phosphorylation to glycolysis (Figure 2) was first introduced by Otto Warburg in $1930[106,109,110]$. This shift in cellular metabolism to a dominant glycolytic state, termed "The Warburg Effect" (aerobic glycolysis), is unexpected as glycolysis is preferentially utilized over mitochondrial respiration, a mechanism that supplies more energy, irrespective of the presence of oxygen $[106,109,110]$.

Since then, the Warburg effect has been extensively studied, with many proposals attempting to reveal both its origins and its promotion of tumorigenesis $[106,109,110]$. Originally, Warburg proposed that damage to mitochondrial respiration (OXPHOS) in all cancers is sufficient for a malignant glycolytic state, thus tumorigenesis is facilitated [116]. It is argued that the silencing of mitochondrial 
respiration, leading to the Warburg effect, is dependent on somatic and hereditary mutations in both nuclear and mitochondrial DNA (mtDNA) [109]. Tumor-promoting mutations have been found in mitochondrial encoded genes within prostate cancers and head and neck tumors [117,118]. Furthermore, nuclear DNA mutations in a number of mitochondria-specific metabolic enzymes have been shown to facilitate tumorigenesis, leading to the formation of paragangliomas and pheochromocytomas $[119,120]$. However, these mutations are considered rare, and are not associated with more commonly occurring cancers such as breast cancer [109]. The Warburg theory has been hotly debated and there is no sound experimental evidence that mitochondrial metabolism is impaired in all cancer cells [121-123]. Apart from a limited range of rare cancers, damage to mitochondrial respiration is not the driver of the glycolytic shift; in fact, many cancers exhibiting the Warburg effect have been shown to retain functional mitochondria (normal OXPHOS) [109]. A biochemist, Sidney Weinhouse, a pioneer in metabolic biochemistry, found that the cancer cell was able to oxide glucose and fatty acids at a similar rate to normal cells [124]. One early explanation was that anaerobic glycolysis was so high in tumor cells that it eliminated the need for oxidative respiration [121]. Hence a chicken-and-egg analogy [125]. Did the mitochondrial dysfunction occur first, pushing the cell to preferentially use glycolysis? Alternatively, did an increased flux in glycolysis occur first, thereby repressing oxidative respiration? Neither viewpoint has been shown to be right or wrong, and this conundrum is discussed in detail in the review by Senyilmaz and Teleman [125]. There is some evidence to suggest that the glycolytic phenotype is characteristic of highly proliferating cells, whereas the switch to oxidative respiration occurs during differentiation [126]. This explanation is in line with our research, which shows that induction of p53 blocks the cell cycle and increases both oxidative respiration and mitochondria biogenesis in breast cancer cells [59,93].

As damage to mitochondrial respiration does not appear to be the cause of glycolytic metabolic dominance, the question is: What are the crucial drivers in the manifestation of Warburg's original observations? High mitochondrial activity and a dependence on mitochondrial and glycolysis metabolism have been shown to be essential for the rapid proliferation of tumors [127,128].

\subsection{How Does p53 Regulate Cancer Metabolism?}

A loss of tumor suppressor proteins, oncogenic mutations within glucose metabolism, and changes in the tumor microenvironment serve as the key drivers of metabolic reprogramming of aerobic glycolysis [12,129-132]. It is only in the last 10-15 years that the link between p53 and aberrant metabolism has been suggested [1,10,15-17,107]. As discussed above (Sections 3.1 and 3.2), enhanced aerobic glycolysis and attenuated mitochondrial respiration facilitate cancer proliferation via energy production and biosynthetic pathways. As summarized in Figure 2, p53 has been shown to downregulate a number of critical components of the glycolytic pathway, including glucose entry into cells $[1,4]$. The net result of p53 activation appears to be the inhibition of the overproduction of pyruvate, the end product of glycolysis, and the promotion of mitochondrial respiration, as exhibited within normal tissue. Typically, cancers preferentially convert this build-up of pyruvate to lactate, but it can be converted to acetyl-CoA by lactate dehydrogenase and pyruvate dehydrogenase (PDH), respectively [10]. p53 has been shown to negatively regulate mitochondrial PDH 2, which increases $\mathrm{PDH}$ activity, thus promoting the conversion of pyruvate to acetyl-CoA instead of lactate, encouraging the TCA cycle, and enhancing mitochondrial respiration [10]. p53 has also been shown to regulate fatty acid oxidation (FAO) by facilitating the transport of fatty acids into the mitochondria via activation of carnitine palmitoyltransferase $1 C$ and by positively regulating the $\beta$-oxidation of fatty acids in response to nutrient stress [10]. This ability of p53 to increase FAO promotes NADH and FADH2 production, which enhances OXPHOS [10]. 


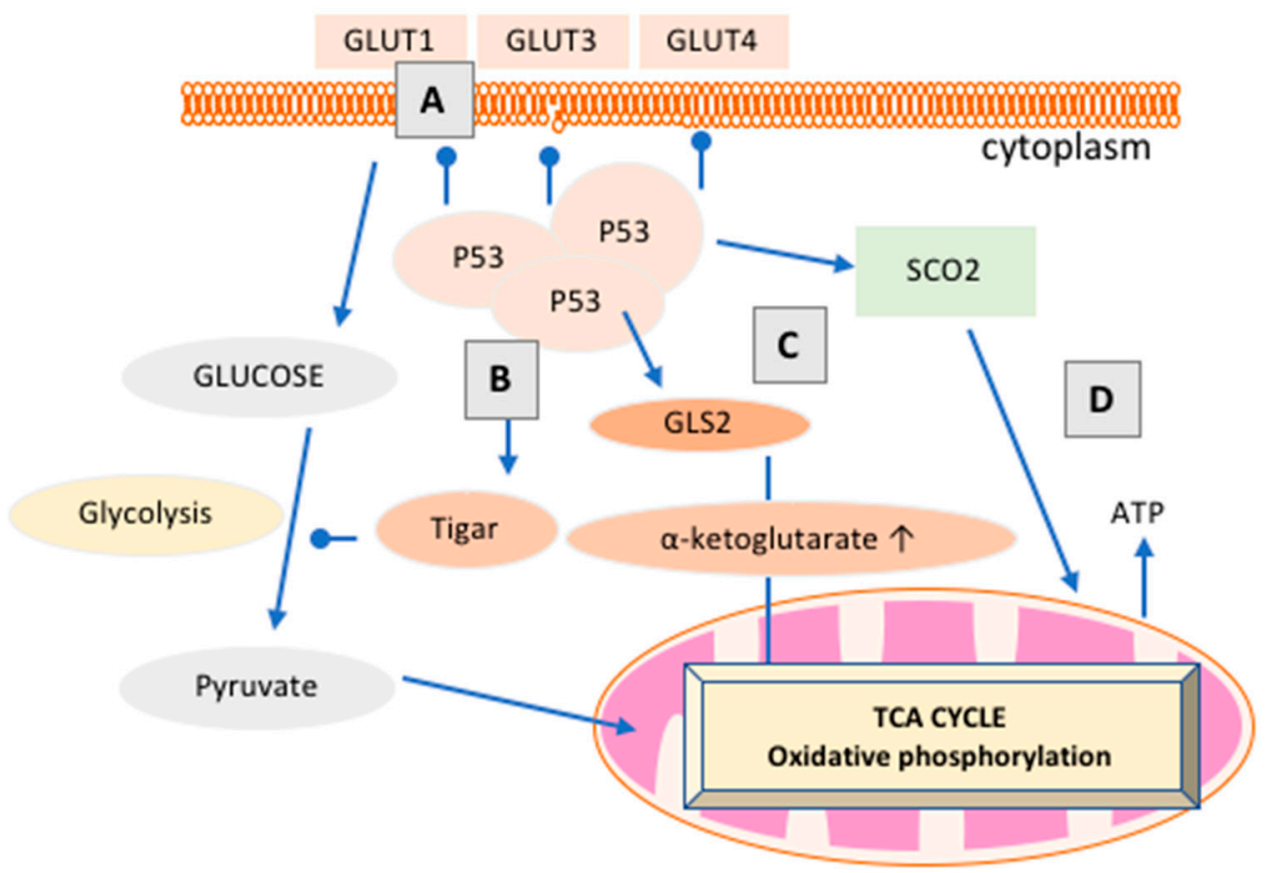

Figure 2. p53 balances glycolysis and mitochondrial respiration. The roles of p53 in cancer metabolism include: (A) suppressing the first step of glycolysis by direct downregulation of glucose-type transporters (GLUT) including GLUT 1, GLUT3, and GLUT4 receptors, which are typically overexpressed in the membranes of cancer cells to facilitate glucose flux $[110,133]$; (B) negative regulation of glycolysis by increasing expression of TP53-induced glycolysis regulator (TIGAR) [133]; (C) regulation of glutaminase-2, leading to an increase in the metabolite $\alpha$-ketoglutarate. This, in turn, promotes the TCA cycle and mitochondrial respiration [134]. (D) The upregulation of the cytochrome C oxidase (COX) complex, via p53 targeting the cytochrome c oxidase assembly protein, increases mitochondrial respiration. COX is a vital transmembrane protein that accepts oxygen in mitochondrial respiration [17]. This figure has been adapted from [1].

Cancer cells typically increase fatty acid uptake and synthesis to meet the demands of membrane biosynthesis, and p53 has been shown to oppose this effect. In contrast, early literature suggests p53 promotes glycolysis in a tissue- and context-specific manner, where p53 is activated to rectify a metabolic stress $[135,136]$. These include the positive regulation of enzymes that control the first rate-limiting step of glycolysis, such as hexokinase II (HK2), by p53 [135,136]. More recently, p53 has been shown to play a crucial role in re-aligning metabolic homeostasis to ensure cell survival during nutrient deprivation [137]. These examples shed light on an emerging view of p53 as a metabolic homeostatic regulator in both normal and cancerous tissue, and not solely as a mediator of the glycolysis and OXPHOS metabolic balance [10].

\subsection{Mitochondrial Dynamics and $p 53$}

Sustaining metabolic homeostasis not only relies on the activity of tumor suppressor proteins such as p53, but also on mitochondrial regulation. This includes controlling mitochondrial size, number and shape through fusion and fission events and intracellular transportation [138,139]. These mechanisms, known as mitochondrial dynamics, ensure optimal mitochondrial bioenergetic function to accommodate energy demands of the cell $[140,141]$. Mitochondrial dynamics has been observed to be influenced by p53 $[57,59,142]$.

The morphology of mitochondria is intimately linked to their functional state $[138,140,141]$. Mitochondrial fission and fusion are critical balancing events that occur to maintain mitochondrial function when cells are exposed to a wide array of metabolic and environmental stresses $[140,141,143]$. 
This includes maintaining mitochondria biomass, number, biogenesis, and their degradation (Figure 3). When fission is unopposed, mitochondrial fragmentation occurs, and is associated with excess glucose abundance, severe stress, cellular death, and impaired OXPHOS. However, fission has also been observed to be vital in the generation of new mitochondria (mitochondrial biogenesis), alongside a quality control process to remove old defective mitochondria, ensuring proper mitochondrial function (Figure 3) [140,141].

Unopposed mitochondrial fusion is observed in mitigating stress during nutrient withdrawal and enhancing OXPHOS rates. This occurs by removing defective mitochondria via the fusing with functionally healthy mitochondria in a complementation process $[140,141]$ (Figure 3 ). There is some evidence that mitochondrial fission and fusion are regulated by p53: Mitofusin2 (mfn2), an integral membrane bound component of fusion, has been shown to be a direct downstream target of p53, implicated in stopping cellular proliferation and sensitizing cell death [57,140].

Within muscle physiology studies, p53 has been observed to regulate alterations in fission and fusion proteins, with p53 knockout (KO) mice displaying acute alterations in mitochondrial morphology and reduced respiratory capacity [58]. This coincided with a former study revealing a loss of mitochondrial function and biomass in p53 KO mice, while wild-type p53 mice maintained mitochondrial biogenesis [142]. The influence of p53 in mitochondrial dynamics is yet to be investigated in breast cancer metabolism, alongside the pivotal role of p53 in mediating the balance between glycolysis and OXPHOS, a current focus in our laboratory. This may prove vital as mitochondrial dynamics appear to serve key metabolic roles towards changing metabolic demands and bioenergetic efficiency of the cell.

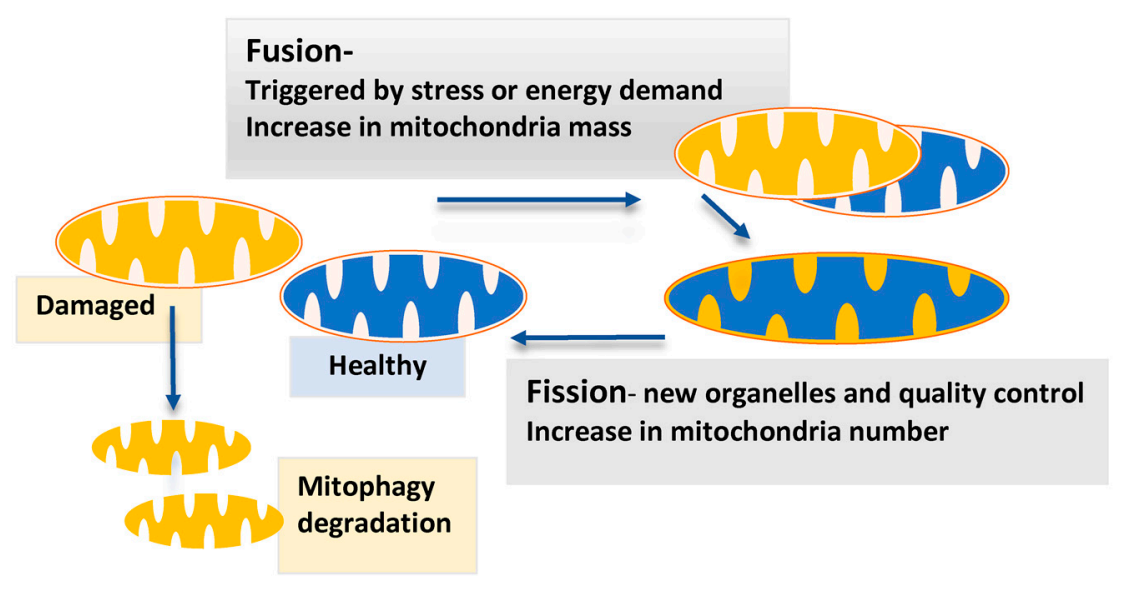

Figure 3. Mitochondrial fission-fusion cycle sustaining mitochondria function, number and genetic health. Under stressful or energy-demanding conditions, mitochondria undergo fusion to complement damaged (yellow) and healthy (blue) mitochondria. This allows for a mixing of constituents alongside increasing membrane surface area, which optimizes bioenergetic functioning. An imbalance between fission and fusion-for instance, greater fission-leads to mitochondrial fragmentation and may increase the number of mitochondria if mitophagy does not eliminate mitochondria. Conversely, more fusion is seen to form large tubular networks. The biogenesis of mitochondria occurs to increase mitochondrial biomass or compensate for mitochondrial degradation. Thus, imbalances between mitochondrial fission, fusion, biogenesis, and degradation appear to regulate the mitochondrial number, shape, size, and biomass [141,144]. Mitochondrial fission has been associated with sensitizing cells to apoptosis during highly stressful conditions and with environments of nutrient excess. However, fission has also been implicated in the "housekeeping" of mitochondria to produce new mitochondria (blue) and remove old/damaged mitochondria. 


\section{5. p53 Family Members $p 63$ and p73 Play Significant Roles in the Cancer Metabolic Switch}

While this review is focused on the functions of the major p53 isoform, some of the smaller alternatively spliced p53 isoforms have been shown to enhance p53 target expression or inhibit p53 wild-type function [145], especially in breast cancer [146]. Two other p53 family members, p63 and p73, also modulate p53 function [4]. Although p53, p63, and p73 isoforms are highly homologues, sharing similar structure and functions as transcriptional factors, studies in KO models of p53, p63, and p73 show functional diversity as well as overlapping functions [147-151]. Interestingly, akin to p53, recent studies show that p63 and p73 isoforms (TAp63, $\Delta$ Np63, Tap73, and $\Delta$ Np73) partake in glucose metabolism [4]. However, this shared relationship proves to be divided, as p63 and p73 isoforms exhibit effects both similar and opposite to those of p53. Whereas p53 is known to inhibit glycolysis and induce fatty acid oxidation, TAp63-null mice develop associated defects in glucose uptake, leading to insulin resistance, obesity, and glucose intolerance. Moreover, although controversy over p53's roles in the phosphate pentose pathway (PPP) lingers, TAp73 appears to enhance PPP flux through increasing the expression of glucose-6-phosphate dehydrogenase, therefore supporting cancer proliferation [152].

As mentioned, p63 and p73 do exhibit similar effects or share overlapping functions with p53. These include TAp63 and TAp73's ability to inhibit glycolysis; the function is similar to that of p53, although the mechanisms vary. Both TAp63 and TAp73 have been shown to induce islet amyloid polypeptide to inhibit glycolysis via inhibiting HK2 [153]. The TAp63 isoform, akin to p53, is associated with inducing GLS2, therefore promoting the TCA cycle [154]. TAp73 is associated with supporting mitochondrial function via oxygen consumption and complex IV stability [155]. This aligns nicely with recent evidence of p53's role in mitochondrial function, as reviewed in [4]. Collectively, p63 and p73 isoforms' effects on glycolysis are influenced by the cellular environment, although they both seem to promote the TCA cycle and PPP.

\section{4. p53 and Breast Cancer Metabolism}

Breast cancer metabolism is diverse and very much dependent on hormone fluctuation [156]. Metabolic rewiring is also determined by breast cancer subtypes [157]. Mutations in p53 have been identified as drivers of aberrance in oxidative respiration and glycolysis in breast cancer, also dependent on the breast cancer sub-type $[156,157]$. Contrary, most hormone-dependent post-menopausal breast cancers, which make up the major breast cancer sub-type, have wt-p53. p53 plays a complex role in normal breast and breast cancer metabolism, complicated by the constant flux of female hormones, as reviewed in [9]. In breast cancer, p53 has been associated with the modulation of key proteins in mitochondrial metabolism, cytochrome c oxidase 2 synthesis, and the TP53-induced glycolysis and apoptosis regulator (TIGAR) [158]. Targeting p53 in its role as a metabolic switch is an exciting but underexplored area of breast cancer treatment. In fact, drugs that target the p53-dependent metabolic checkpoint such as metformin (a commonly used medication for type 2 diabetes to reduce glucose production) are undergoing clinical trials in combination with established therapies [159].

\subsection{Upstream Regulation and Reactivation of p53 in Breast Cancer}

As mentioned in Section 1.2, only $20-30 \%$ of breast cancers sustain TP53 mutations, leaving $\sim 70 \%$ retaining functional wild-type-p53 (wt-p53) [43,44]. Under homeostatic conditions, cellular p53 protein levels are low due to its short half-life and continual degradation by the HDM2 ubiquitin ligase $[160,161]$. Due to the large proportion of breast carcinomas retaining wt-p53, radiotherapy and chemotherapy agents such as doxorubicin are successful in reactivating p53 via the DNA damage pathway, inducing cell cycle arrest and cell death [25-27]. In line with its classical role as a tumor suppressor, novel anti-HDM2 (human double minute 2) agents target HDM2, stabilize p53, and reactivate the p53 signaling pathway to kill cancer cells [27,162-164]. Nutlin-3a is one such chemical repressor; by binding HDM2, nutlin 3a reduces HDM2 function, thus stabilizing p53, and has been 
found to be efficacious in both in vivo and in vitro models, including breast cancer. It is currently undergoing phase III clinical trials [162-165].

p53 is commonly silenced in breast cancer by loss of upstream/downstream mechanisms. A key natural, endogenous regulator of $\mathrm{p} 53$ is the tumor suppressor $\mathrm{p} 14$ alternative reading frame (p14ARF). The p14ARF protein is an upstream positive regulator of p53 through its binding to HDM2 and preventing p53 degradation, thus stabilizing p53 expression and activating p53 function [166-168] (Figure 4).

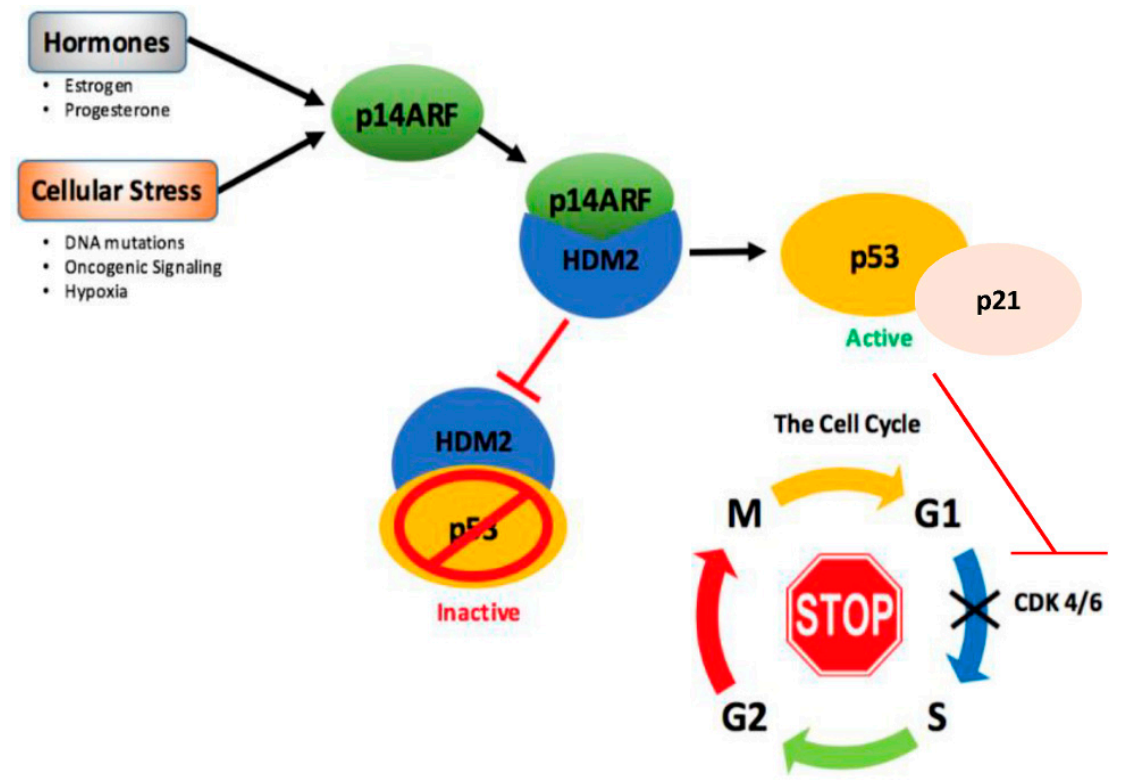

Figure 4. The p14ARF-p53 pathway. HDM2 sustains low basal levels of p53 by its continuous degradation $[160,161]$. p14ARF, activated by cellular stress signals and potentially regulated by estrogen and progesterone hormones in the breast [93,168-171], causes inhibition of the HDM2-p53 complex, therefore stabilizing p53. p53 is able to bring about cell cycle arrest at the G1/S phase through the activation of the CDK inhibitor p21, which inhibits downstream CDK 4 and $6[66,68,69]$. Both CDK 4 and 6 are well-known mediators of G1/S cell cycle progression, hence their inhibition by p21 halts the cell cycle [66].

p14ARF is activated in response to adverse environmental stimuli to prevent hyperproliferation of cells to prevent cancer. The upstream p53 regulator, p14ARF, is silenced by methylation, deletion, or mutation in many breast cancers $[166,172,173]$. As such, therapeutic interest in re-activating the p14ARF-p53 pathway via re-introducing p14ARF or utilizing p14ARF mimetics to induce p53 (such as Nutlin-3a) has gained momentum. Early studies into re-activating the p14ARF-p53 pathway within breast cancer cells revealed rapid induction of apoptosis. However, these models utilized an adenoviral vector system expressing high, non-physiologically relevant levels of p53 [174]. Our laboratory has developed an inducible vector system to express controlled, physiologically relevant levels of p14ARF to activate the p53 signaling pathway in hormone-dependent breast cancer cells $[59,93]$. These studies demonstrated that p14ARF induces the p53-p21-retinoblastoma ( $R b)$ pathway to induce cell cycle arrest; however, the cells did not undergo apoptosis, but remained metabolically active and viable $[59,93]$. Our studies linked the activation of p14ARF-p53 signaling directly to changes in breast cancer cellular metabolism.

\section{2. p53 Regulates Mitochondria Dynamics in Breast Cancer}

Although mitochondrial dynamics has been observed to be influenced by p53 (Section 3.4), there is very little understanding of this process in breast cancer. In breast cancer, as in most cancers, p53 is 
reactivated by chemotherapy or radiation therapy to induce mitochondria-mediated cell death or permanent cell cycle arrest (Section 2.1). In our studies, in the absence of external stress factors, p14ARF re-activation of the p53 pathway rapidly induced cell cycle arrest (within $6 \mathrm{~h}$ ) in breast cancer cells. Instead of the expected classical p53-mitochondria-induced apoptosis, p53 promoted major metabolic reprogramming in hormone-dependent breast cancer cells in favor of increased cellular function and viability [59,93]. Mitochondrial biomass, membrane potentiality, and mitochondria activity were enhanced, as well as metabolic and cellular morphological changes $[59,93]$. Therefore, p53 may be regarded as a pendulum between mitochondrial survival on one hand and mitochondrial-induced cell death on the other, depending on the cellular environment. Reactivation of the p14ARF-p53 pathway in ER+ breast cancer cells did not overtly alter the p53-dependent annexin A5 apoptotic marker associated with mitochondria-mediated cell death $[59,93,94]$. However, expression of other annexin family members and associated proteins, which control calcium flux, were enhanced $[59,93,94]$. Our findings supported the role of p53 as a key orchestrator of annexin/S100A regulation. In this study, annexins A1, A2, A4, A6, and A9 were upregulated downstream of the p53 signaling pathway [94]. Although the consequences of p53 differential regulation of the annexins/S100A family is not clear, intracellular calcium homeostasis and regulation of mitochondria function are not mutually exclusive [175]. For example, A6 has been reported to be an important protein in the regulation of mitochondrial morphogenesis, fission, and fusion, and loss of A6 expression is associated with fragmented mitochondria and impaired membrane potentiality and impaired oxidative respiration [176]. Regulation of calcium signaling is essential for mammary gland function and deregulation of calcium homeostasis is associated with cancer pathophysiology.

This p53-attenuated apoptosis aligns nicely with a series of studies, illustrating that the estrogen receptor $(E R \alpha)$ interacts with p53, leading to an intrusion in p53 downstream signaling targets [177-179]. ER $\alpha$ signaling pathways and its expression within cancer and normal breast physiology have been extensively documented [180-182]; however, the interaction between ER $\alpha$ and p53 is novel within breast cancer. Konduri and colleagues first observed that p53 and ER $\alpha$ interact directly, leading to the downregulation of p53 alongside its downstream signaling targets such as p21 [178]. Further investigations by Brown and colleagues confirmed this interaction and showed that repression of $\mathrm{p} 53$ by ER $\alpha$ led to a lack of repression of genes involved in resisting apoptosis, thus hindering the ability of p53 to prompt apoptosis [177]. The data suggest a mechanism of resistance to treatments mediated through $\mathrm{ER} \alpha$, whereby functionally active p53 can become repressed in ER+ breast cancers. This also begs the question, does p53 interaction with ER+ in normal breast physiology to prevent cell death and divert the course of metabolic function?

\subsection{Novel Avenues for Targeting p53 in Drug Resistance, Recurrence, and Metastasis in Breast Cancer}

Increasing evidence supports the notion that dysregulated metabolism confers drug resistance and recurrence in breast cancer [156]. Breast cancer cells, like most cancer cells, use glucose and glutamine to survive, so, conceptually, targeting the energy-related metabolic pathways for therapeutic intervention in breast cancer is an exciting idea [183]. However, there is a fine balance between p53 regulation of mitochondrial processes, cell death, or cell survival in normal and cancer tissues. Therefore, targeting metabolism to prevent breast cancer recurrence has inherent problems: (1) All normal and cancer cells utilize both glycolysis and oxidative respiration for energy requirements; (2) different sub-types of breast cancer have different metabolic requirements and p53 status; (3) the complexities associated with the constant changes in breast metabolism and the emerging cross-talk of p53 with hormone receptors and other signaling pathways. This requires a more in-depth understanding of the intricacies of p53's influence on metabolism in normal and breast cancer cells.

An interesting advancement in our understanding of maladaptive metabolism and cancer came from studies in exercise physiology. Exercise, which alters cellular metabolism, has long been known to reduce breast cancer risk [184]. Aerobic exercise has long been known to increase mitochondria function and lactate clearance, and as well as to decrease glycolysis [185]. Lactate, once considered a waste 
product of anaerobic metabolism, is now regarded as an important fuel for cancer cell development and metastasis [186]. In addition, aerobic exercise has been shown to increase fat oxidation [187] As demonstrated in skeletal muscle, during exercise, p53 is a key molecule in substrate metabolic regulation and exercise-induced mitochondrial biogenesis, thus increasing mitochondrial respiratory activity [188]. As mentioned in Section 3.4, p53 regulates alterations in fission and fusion proteins, maintaining mitochondria morphology and respiratory capacity in muscle [58]. Perhaps a clearer understanding of the effects of exercise on p53-cellular metabolic reprogramming may provide clues for the prevention of breast cancer and new avenues for breast cancer treatment options.

\section{Conclusions}

The studies highlighted in this review reveal that p53 has a plethora of functions in normal and cancer metabolism beyond the classical mitochondrial death syndrome. Our major research focus is on understanding hormone-dependent cancer origin, treatment resistance, and recurrence in breast cancer. It is important to understand the role of p53 in the regulation of cancer metabolism as well as its underlying mechanism and how it applies directly to breast cancer. The mitochondrial targets of p53 that are unfolding would provide a platform to further investigate the role of p53 in modulating mitochondrial metabolic pathways. Future studies would include confirming p53 interactions with the aforementioned mitochondrial proteins, along with formulating a cohesive timeline for the changing metabolic phenotypes associated with p53's evolving role as a master metabolic regulator in normal mammary cells and breast cancer cell evolution.

The ultimate goal will be to elucidate the metabolic functions of p53 within breast cancer metabolism, which will reveal critical metabolic hotspots that cancers advantageously re-engineered for sustenance. Full understanding of these events would pave the way for the development of novel therapeutics targeting breast cancer metabolism and eventually new strategies to fight breast cancer.

Funding: This research received no external funding

Acknowledgments: D.H. received an Australian Postgraduate Award.

Conflicts of Interest: The authors declare no conflict of interest.

\section{References}

1. Vousden, K.H.; Ryan, K.M. P53 and metabolism. Nat. Rev. Cancer 2009, 9, 691-700. [CrossRef] [PubMed]

2. Vousden, K.H.; Prives, C. Blinded by the light: The growing complexity of p53. Cell 2009, 137, 413-431. [CrossRef] [PubMed]

3. Levine, A.J.; Oren, M. The first 30 years of p53: Growing ever more complex. Nat. Rev. Cancer 2009, 9, 749-758. [CrossRef] [PubMed]

4. Itahana, Y.; Itahana, K. Emerging roles of p53 family members in glucose metabolism. Int. J. Mol. Sci. 2018, 19, 776. [CrossRef] [PubMed]

5. Gnanapradeepan, K.; Basu, S.; Barnoud, T.; Budina-Kolomets, A.; Kung, C.P.; Murphy, M.E. The p53 tumor suppressor in the control of metabolism and ferroptosis. Front. Endocrinol. 2018, 9, 124. [CrossRef] [PubMed]

6. Vousden, K.H. Functions of p53 in metabolism and invasion. Biochem. Soc. Trans. 2009, 37, 511-517. [CrossRef] [PubMed]

7. De Santis, M.C.; Porporato, P.E.; Martini, M.; Morandi, A. Signaling pathways regulating redox balance in cancer metabolism. Front. Oncol. 2018, 8, 126. [CrossRef] [PubMed]

8. Olovnikov, I.A.; Kravchenko, J.E.; Chumakov, P.M. Homeostatic functions of the p53 tumor suppressor: Regulation of energy metabolism and antioxidant defense. Semin. Cancer Biol. 2009, 19, 32-41. [CrossRef] [PubMed]

9. McGowan, E.M.; Lin, Y.; Hatoum, D. Good guy or bad guy? The duality of wild-type p53 in breast cancer origin, treatment, and recurrence. Cancers 2018, 10, 172. [CrossRef] [PubMed]

10. Kruiswijk, F.; Labuschagne, C.F.; Vousden, K.H. p53 in survival, death and metabolic health: A lifeguard with a licence to kill. Nat. Rev. Mol. Cell Biol. 2015, 16, 393-405. [CrossRef] [PubMed] 
11. Balint, E.E.; Vousden, K.H. Activation and activities of the p53 tumour suppressor protein. Br. J. Cancer 2001, 85, 1813-1823. [CrossRef] [PubMed]

12. Cairns, R.A.; Harris, I.S.; Mak, T.W. Regulation of cancer cell metabolism. Nat. Rev. Cancer 2011, 11, 85-95. [CrossRef] [PubMed]

13. DeBerardinis, R.J.; Lum, J.J.; Hatzivassiliou, G.; Thompson, C.B. The biology of cancer: Metabolic reprogramming fuels cell growth and proliferation. Cell Metab. 2008, 7, 11-20. [CrossRef] [PubMed]

14. Cairns, R.A.; Mak, T.W. The current state of cancer metabolism. Nat. Rev. Cancer 2016, 16, 613-614. [CrossRef]

15. Liu, J.; Zhang, C.; Hu, W.; Feng, Z. Tumor suppressor p53 and its mutants in cancer metabolism. Cancer Lett. 2015, 356, 197-203. [CrossRef] [PubMed]

16. Berkers, C.R.; Maddocks, O.D.K.; Cheung, E.C.; Mor, I.; Vousden, K.H. Metabolic regulation by p53 family members. Cell Metab. 2013, 18, 617-633. [CrossRef] [PubMed]

17. Matoba, S.; Kang, J.G.; Patino, W.D.; Wragg, A.; Boehm, M.; Gavrilova, O.; Hurley, P.J.; Bunz, F.; Hwang, P.M. p53 regulates mitochondrial respiration. Science 2006, 312, 1650-1653. [CrossRef] [PubMed]

18. Stewart, B.; Wild, C.P. World Cancer Report 2014; WHO: Geneva, Switzerland, 2017.

19. Jemal, A.; Ward, E.M.; Johnson, C.J.; Cronin, K.A.; Ma, J.; Ryerson, B.; Mariotto, A.; Lake, A.J.; Wilson, R.; Sherman, R.L.; et al. Annual report to the nation on the status of cancer, 1975-2014, featuring survival. J. Natl. Cancer Inst. 2017, 109. [CrossRef] [PubMed]

20. Ghoncheh, M.; Pournamdar, Z.; Salehiniya, H. Incidence and mortality and epidemiology of breast cancer in the world. Asian Pac. J. Cancer Prev. 2016, 17, 43-46. [CrossRef] [PubMed]

21. Clarke, R.; Tyson, J.J.; Dixon, J.M. Endocrine resistance in breast cancer-An overview and update. Mol. Cell. Endocrinol. 2015, 418, 220-234. [CrossRef] [PubMed]

22. Althuis, M.D.; Fergenbaum, J.H.; Garcia-Closas, M.; Brinton, L.A.; Madigan, M.P.; Sherman, M.E. Etiology of hormone receptor-defined breast cancer: A systematic review of the literature. Cancer Epidemiol. Biomark. Prev. 2004, 13, 1558-1568.

23. Allred, D.C. Issues and updates: Evaluating estrogen receptor- $\alpha$, progesterone receptor, and HER2 in breast cancer. Mod. Pathol. 2010, 23, S52-S59. [CrossRef] [PubMed]

24. Coates, A.S.; Winer, E.P.; Goldhirsch, A.; Gelber, R.D.; Gnant, M.; Piccart-Gebhart, M.; Thürlimann, B.; Senn, H.-J. Tailoring therapies-Improving the management of early breast cancer: St galleninternational expert consensus on the primary therapy of early breast cancer 2015. Ann. Oncol. 2015, 26, 1533-1546. [CrossRef] [PubMed]

25. Wang, S.; Konorev, E.A.; Kotamraju, S.; Joseph, J.; Kalivendi, S.; Kalyanaraman, B. Doxorubicin induces apoptosis in normal and tumor cells via distinctly different mechanisms: Intermediacy of $\mathrm{H}_{2} \mathrm{O}_{2}$ - and p53-dependent pathways. J. Biol. Chem. 2004, 279, 25535-25543. [CrossRef] [PubMed]

26. Smith, L.; Watson, M.B.; O’Kane, S.L.; Drew, P.J.; Lind, M.J.; Cawkwell, L. The analysis of doxorubicin resistance in human breast cancer cells using antibody microarrays. Mol. Cancer Ther. 2006, 5, 2115-2120. [CrossRef] [PubMed]

27. Balmer, M.T.; Katz, R.D.; Liao, S.; Goodwine, J.S.; Gal, S. Doxorubicin and 5-fluorouracil induced accumulation and transcriptional activity of p53 are independent of the phosphorylation at serine 15 in MCF-7 breast cancer cells. Cancer Biol. Ther. 2014, 15, 1000-1012. [CrossRef] [PubMed]

28. Gudkov, A.V.; Komarova, E.A. The role of p53 in determining sensitivity to radiotherapy. Nat. Rev. Cancer 2003, 3, 117-129. [CrossRef] [PubMed]

29. Pinto, A.C.; Ades, F.; de Azambuja, E.; Piccart-Gebhart, M. Trastuzumab for patients with HER2 positive breast cancer: Delivery, duration and combination therapies. Breast 2013, 22, S152-S155. [CrossRef] [PubMed]

30. Johnston, S.R.D.; Dowsett, M. Aromatase inhibitors for breast cancer: Lessons from the laboratory. Nat. Rev. Cancer 2003, 3, 821-831. [CrossRef] [PubMed]

31. Dai, X.; Chen, A.; Bai, Z. Integrative investigation on breast cancer in ER, PR and HER2-defined subgroups using mrna and mirna expression profiling. Sci. Rep. 2014, 4, 6566. [CrossRef] [PubMed]

32. Hudis, C.A.; Gianni, L. Triple-negative breast cancer: An unmet medical need. Oncologist 2011, 16, 1-11. [CrossRef] [PubMed]

33. Chen, L.; Linden, H.M.; Anderson, B.O.; Li, C.I. Trends in 5-year survival rates among breast cancer patients by hormone receptor status and stage. Breast Cancer Res. Treat. 2014, 147, 609-616. [CrossRef] [PubMed] 
34. Liu, C.Y.; Wu, C.Y.; Petrossian, K.; Huang, T.T.; Tseng, L.M.; Chen, S. Treatment for the endocrine resistant breast cancer: Current options and future perspectives. J. Steroid Biochem. Mol. Biol. 2017, 172, 166-175. [CrossRef] [PubMed]

35. Tryfonidis, K.; Zardavas, D.; Katzenellenbogen, B.S.; Piccart, M. Endocrine treatment in breast cancer: Cure, resistance and beyond. Cancer Treat. Rev. 2016, 50, 68-81. [CrossRef] [PubMed]

36. Early Breast Cancer Trialists' Collaborative Group. Effects of chemotherapy and hormonal therapy for early breast cancer on recurrence and 15-year survival: An overview of the randomised trials. Lancet 2005, 365, 1687-1717.

37. Ma, C.X.; Sanchez, C.G.; Ellis, M.J. Predicting endocrine therapy responsiveness in breast cancer. Oncology 2009, 23, 133-142. [PubMed]

38. Roy, R.; Chun, J.; Powell, S.N. Brca1 and brca2: Different roles in a common pathway of genome protection. Nat. Rev. Cancer 2012, 12, 68-78. [CrossRef] [PubMed]

39. Muller, P.A.J.; Vousden, K.H. p53 mutations in cancer. Nat. Cell Biol. 2013, 15, 2-8. [CrossRef] [PubMed]

40. Yang, P.; Du, C.W.; Kwan, M.; Liang, S.X.; Zhang, G.J. The impact of p53 in predicting clinical outcome of breast cancer patients with visceral metastasis. Sci. Rep. 2013, 3, 2246. [CrossRef] [PubMed]

41. Alsner, J.; Yilmaz, M.; Guldberg, P.; Hansen, L.L.; Overgaard, J. Heterogeneity in the clinical phenotype of TP53 mutations in breast cancer patients. Am. Assoc. Cancer Res. 2000, 6, 3923-3931. [CrossRef]

42. Fresno Vara, J.A.; Casado, E.; de Castro, J.; Cejas, P.; Belda-Iniesta, C.; Gonzalez-Baron, M. PI3K/AKT signalling pathway and cancer. Cancer Treat. Rev. 2004, 30, 193-204. [CrossRef] [PubMed]

43. Bertheau, P.; Espié, M.; Turpin, E.; Lehmann, J.; Plassa, L.F.; Varna, M.; Janin, A.; de Thé, H. TP53 status and response to chemotherapy in breast cancer. Pathobiology 2008, 75, 132-139. [CrossRef] [PubMed]

44. Bertheau, P.; Lehmann-Che, J.; Varna, M.; Dumay, A.; Poirot, B.; Porcher, R.; Turpin, E.; Plassa, L.F.; de Roquancourt, A.; Bourstyn, E.; et al. p53 in breast cancer subtypes and new insights into response to chemotherapy. Breast 2013, 22, S27-S29. [CrossRef] [PubMed]

45. McBride, H.M.; Neuspiel, M.; Wasiak, S. Mitochondria: More than just a powerhouse. Curr. Biol. 2006, 16, R551-R560. [CrossRef] [PubMed]

46. Bosc, C.; Selak, M.A.; Sarry, J.E. Resistance is futile: Targeting mitochondrial energetics and metabolism to overcome drug resistance in cancer treatment. Cell Metab. 2017, 26, 705-707. [CrossRef] [PubMed]

47. Vousden, K.H.; Lu, X. Live or let die: The cell's response to p53. Nat. Rev. Cancer 2002, 2, 594-604. [CrossRef] [PubMed]

48. Bieging, K.T.; Mello, S.S.; Attardi, L.D. Unravelling mechanisms of p53-mediated tumour suppression. Nat. Rev. Cancer 2014, 14, 359-370. [CrossRef] [PubMed]

49. Khoo, K.H.; Verma, C.S.; Lane, D.P. Drugging the p53 pathway: Understanding the route to clinical efficacy. Nat. Rev. Drug Discov. 2014, 13, 217-236. [CrossRef] [PubMed]

50. Xie, Y.; Hou, W.; Song, X.; Yu, Y.; Huang, J.; Sun, X.; Kang, R.; Tang, D. Ferroptosis: Process and function. Cell Death Differ. 2016, 23, 369-379. [CrossRef] [PubMed]

51. Galluzzi, L.; Bravo-San Pedro, J.M.; Kroemer, G. Ferroptosis in p53-dependent oncosuppression and organismal homeostasis. Cell Death Differ. 2015, 22, 1237-1238. [CrossRef] [PubMed]

52. Baumann, K. Cell death: Multitasking p53 promotes necrosis. Nat. Rev. Mol. Cell Biol. 2012, 13, $480-481$. [CrossRef] [PubMed]

53. Green, D.R.; Kroemer, G. Cytoplasmic functions of the tumour suppressor p53. Nature 2009, 458, 1127-1130. [CrossRef] [PubMed]

54. Wu, W.; Liu, P.; Li, J. Necroptosis: An emerging form of programmed cell death. Crit. Rev. Oncol. Hematol. 2012, 82, 249-258. [CrossRef] [PubMed]

55. Zhao, L.; Wang, B.; Zhao, X.; Wu, X.; Zhang, Q.; Wei, C.; Shi, M.; Li, Y.; Tang, W.; Zhang, J.; et al. Gain of function in the mouse model of a recurrent mutation p53(n236s) promotes the formation of double minute chromosomes and the oncogenic potential of p19(ARF). Mol. Carcinog. 2018, 57, 147-158. [CrossRef] [PubMed]

56. Escoll, M.; Gargini, R.; Cuadrado, A.; Anton, I.M.; Wandosell, F. Mutant p53 oncogenic functions in cancer stem cells are regulated by WIP through YAP/TAZ. Oncogene 2017, 36, 3515-3527. [CrossRef] [PubMed]

57. Wang, W.; Cheng, X.; Lu, J.; Wei, J.; Fu, G.; Zhu, F.; Jia, C.; Zhou, L.; Xie, H.; Zheng, S. Mitofusin-2 is a novel direct target of p53. Biochem. Biophys. Res. Commun. 2010, 400, 587-592. [CrossRef] [PubMed] 
58. Saleem, A.; Iqbal, S.; Zhang, Y.; Hood, D.A. Effect of p53 on mitochondrial morphology, import, and assembly in skeletal muscle. Am. J. Physiol. Cell Physiol. 2015, 308, C319-C329. [CrossRef] [PubMed]

59. McGowan, E.M.; Alling, N.; Jackson, E.A.; Yagoub, D.; Haass, N.K.; Allen, J.D.; Martinello-Wilks, R. Evaluation of cell cycle arrest in estrogen responsive MCF-7 breast cancer cells: Pitfalls of the mts assay. PLoS ONE 2011, 6, e20623. [CrossRef] [PubMed]

60. Freed-Pastor, W.A.; Prives, C. Mutant p53: One name, many proteins. Genes Dev. 2012, 26, 1268-1286. [CrossRef] [PubMed]

61. Bykov, V.J.N.; Issaeva, N.; Shilov, A.; Hultcrantz, M.; Pugacheva, E.; Chumakov, P.; Bergman, J.; Wiman, K.G.; Selivanova, G. Restoration of the tumor suppressor function to mutant p53 by a low-molecular-weight compound. Nat. Med. 2002, 8, 282-288. [CrossRef] [PubMed]

62. Riley, T.; Sontag, E.; Chen, P.; Levine, A. Transcriptional control of human p53-regulated genes. Nat. Rev. Mol. Cell Biol. 2008, 9, 402-412. [CrossRef] [PubMed]

63. Menendez, D.; Inga, A.; Resnick, M.A. The expanding universe of p53 targets. Nat. Rev. Cancer 2009, 9, 724-737. [CrossRef] [PubMed]

64. Proskuryakov, S.Y.; Konoplyannikov, A.G.; Gabai, V.L. Necrosis: A specific form of programmed cell death? Exp. Cell Res. 2003, 283, 1-16. [CrossRef]

65. Lakin, N.D.; Jackson, S.P. Regulation of p53 in response to DNA damage. Oncogene 1999, 18, 7644-7655. [CrossRef] [PubMed]

66. He, G.; Siddik, Z.H.; Huang, Z.; Wang, R.; Koomen, J.; Kobayashi, R.; Khokhar, A.R.; Kuang, J. Induction of p21 by p53 following DNA damage inhibits both CDK4 and CDK2 activities. Oncogene 2005, 24, 2929-2943. [CrossRef] [PubMed]

67. Brooks, C.L.; Gu, W. New insights into p53 activation. Cell Res. 2010, 20, 614-621. [CrossRef] [PubMed]

68. Musgrove, E.A.; Caldon, C.E.; Barraclough, J.; Stone, A.; Sutherland, R.L. Cyclin D as a therapeutic target in cancer. Nat. Rev. Cancer 2011, 11, 558-572. [CrossRef] [PubMed]

69. Abbas, T.; Dutta, A. p21 in cancer: Intricate networks and multiple activities. Nat. Rev. Cancer 2009, 9, 400-414. [CrossRef] [PubMed]

70. Poletto, M.; Legrand, A.J.; Fletcher, S.C.; Dianov, G.L. p53 coordinates base excision repair to prevent genomic instability. Nucleic Acids Res. 2016, 44, 3165-3175. [CrossRef] [PubMed]

71. Smith, M.L.; Seo, Y.R. p53 regulation of DNA excision repair pathways. Mutagenesis 2002, 17, $149-156$. [CrossRef] [PubMed]

72. Nakano, K.; Vousden, K.H. Puma, a novel proapoptotic gene, is induced by p53. Mol. Cell 2001, 7, 683-694. [CrossRef]

73. Jeffers, J.R.; Parganas, E.; Lee, Y.; Yang, C.; Wang, J.; Brennan, J.; MacLean, K.H.; Han, J.; Chittenden, T.; Ihle, J.N.; et al. Puma is an essential mediator of p53-dependent and -independent apoptotic pathways. Cancer Cell 2003, 4, 321-328. [CrossRef]

74. Oda, E.; Ohki, R.; Murasawa, H.; Nemoto, J.; Shibue, T.; Yamashita, T.; Tokino, T.; Taniguchi, T.; Tanaka, N. Noxa, a BH3-only member of the Bcl-2 family and candidate mediator of p53-induced apoptosis. Science 2000, 288, 1053-1058. [CrossRef] [PubMed]

75. Chipuk, J.E. Direct activation of Bax by p53 mediates mitochondrial membrane permeabilization and apoptosis. Science 2004, 303, 1010-1014. [CrossRef] [PubMed]

76. Fridman, J.S.; Lowe, S.W. Control of apoptosis by p53. Oncogene 2003, 22, 9030-9040. [CrossRef] [PubMed]

77. Galluzzi, L.; Kepp, O.; Krautwald, S.; Kroemer, G.; Linkermann, A. Molecular mechanisms of regulated necrosis. Semin. Cell Dev. Biol. 2014, 35, 24-32. [CrossRef] [PubMed]

78. Su, Z.; Yang, Z.; Xie, L.; DeWitt, J.P.; Chen, Y. Cancer therapy in the necroptosis era. Cell Death Differ. 2016, 23, 748-756. [CrossRef] [PubMed]

79. Chan, F.K.; Luz, N.F.; Moriwaki, K. Programmed necrosis in the cross talk of cell death and inflammation. Annu. Rev. Immunol. 2015, 33, 79-106. [CrossRef] [PubMed]

80. Rabinowitz, J.D.; White, E. Autophagy and metabolism. Science 2010, 330, 1344. [CrossRef] [PubMed]

81. Mizushima, N.; Levine, B.; Cuervo, A.M.; Klionsky, D.J. Autophagy fights disease through cellular self-digestion. Nature 2008, 451, 1069-1075. [CrossRef] [PubMed]

82. Maiuri, M.C.; Galluzzi, L.; Morselli, E.; Kepp, O.; Malik, S.A.; Kroemer, G. Autophagy regulation by p53. Curr. Opin. Cell Biol. 2010, 22, 181-185. [CrossRef] [PubMed] 
83. Tasdemir, E.; Maiuri, M.C.; Galluzzi, L.; Vitale, I.; Djavaheri-Mergny, M.; D’Amelio, M.; Criollo, A.; Morselli, E.; Zhu, C.; Harper, F.; et al. Regulation of autophagy by cytoplasmic p53. Nat. Cell Biol. 2008, 10, 676-687. [CrossRef] [PubMed]

84. Levine, B.; Abrams, J. P53: The janus of autophagy? Nat. Cell Biol. 2008, 10, 637-639. [CrossRef] [PubMed]

85. Tasdemir, E.; Chiara Maiuri, M.; Morselli, E.; Criollo, A.; D’Amelio, M.; Djavaheri-Mergny, M.; Cecconi, F.; Tavernarakis, N.; Kroemer, G. A dual role of p53 in the control of autophagy. Autophagy 2008, 4, 810-814. [CrossRef] [PubMed]

86. Okamoto, K.; Kondo-Okamoto, N. Mitochondria and autophagy: Critical interplay between the two homeostats. Biochim. Biophys. Acta 2012, 1820, 595-600. [CrossRef] [PubMed]

87. Levy, J.M.M.; Towers, C.G.; Thorburn, A. Targeting autophagy in cancer. Nat. Rev. Cancer 2017, 17, 528-542. [CrossRef] [PubMed]

88. Manjili, M.H. Tumor dormancy and relapse: From a natural byproduct of evolution to a disease state. Cancer Res. 2017, 77, 2564-2569. [CrossRef] [PubMed]

89. Babot, M.; Galkin, A. Molecular mechanism and physiological role of active-deactive transition of mitochondrial complex i. Biochem. Soc. Trans. 2013, 41, 1325-1330. [CrossRef] [PubMed]

90. Karrison, T.G.; Ferguson, D.J.; Meier, P. Dormancy of mammary carcinoma after mastectomy. J. Natl. Cancer Inst. 1999, 91, 80-85. [CrossRef] [PubMed]

91. Aguirre-Ghiso, J.A. Models, mechanisms and clinical evidence for cancer dormancy. Nat. Rev. Cancer 2007, 7, 834-846. [CrossRef] [PubMed]

92. Mathew, R.; Karantza-Wadsworth, V.; White, E. Role of autophagy in cancer. Nat. Rev. Cancer 2007, 7, 961-967. [CrossRef] [PubMed]

93. McGowan, E.M.; Tran, N.; Alling, N.; Yagoub, D.; Sedger, L.M.; Martiniello-Wilks, R. P14arf post-transcriptional regulation of nuclear cyclin d1 in MCF-7 breast cancer cells: Discrimination between a good and bad prognosis? PLoS ONE 2012, 7, e42246. [CrossRef] [PubMed]

94. Hatoum, D.; Yagoub, D.; Ahadi, A.; Nassif, N.T.; McGowan, E.M. Annexin/s100a protein family regulation through p14arf-p53 activation: A role in cell survival and predicting treatment outcomes in breast cancer. PLoS ONE 2017, 12, e0169925. [CrossRef] [PubMed]

95. Chen, Z.; Trotman, L.C.; Shaffer, D.; Lin, H.-K.; Dotan, Z.A.; Niki, M.; Koutcher, J.A.; Scher, H.I.; Ludwig, T.; Gerald, W.; et al. Crucial role of p53-dependent cellular senescence in suppression of PTEN-deficient tumorigenesis. Nature 2005, 436, 725-730. [CrossRef] [PubMed]

96. Rufini, A.; Tucci, P.; Celardo, I.; Melino, G. Senescence and aging: The critical roles of p53. Oncogene 2013, 32, 5129-5143. [CrossRef] [PubMed]

97. Xue, W. Senescence and tumour clearance is triggered by p53 restoration in murine liver carcinomas. Nature 2007, 445, 656-660. [CrossRef] [PubMed]

98. Qian, Y.; Chen, X. Senescence regulation by the p53 protein family. Methods Mol. Biol. 2013, 965, 37-61. [PubMed]

99. Itahana, K.; Dimri, G.P.; Hara, E.; Itahana, Y.; Zou, Y.; Desprez, P.-Y.; Campisi, J. A role for p53 in maintaining and establishing the quiescence growth arrest in human cells. J. Biol. Chem. 2002, 277, 18206-18214. [CrossRef] [PubMed]

100. Liu, Y.; Elf, S.E.; Miyata, Y.; Sashida, G.; Liu, Y.; Huang, G.; Di Giandomenico, S.; Lee, J.M.; Deblasio, A.; Menendez, S.; et al. p53 regulates hematopoietic stem cell quiescence. Cell Stem Cell 2009, 4, 37-48. [CrossRef] [PubMed]

101. Dixon, S.J.; Lemberg, K.M.; Lamprecht, M.R.; Skouta, R.; Zaitsev, E.M.; Gleason, C.E.; Patel, D.N.; Bauer, A.J.; Cantley, A.M.; Yang, W.S.; et al. Ferroptosis: An iron-dependent form of nonapoptotic cell death. Cell 2012, 149, 1060-1072. [CrossRef] [PubMed]

102. Wu, C.; Zhao, W.; Yu, J.; Li, S.; Lin, L.; Chen, X. Induction of ferroptosis and mitochondrial dysfunction by oxidative stress in PC12 cells. Sci. Rep. 2018, 8, 574. [CrossRef] [PubMed]

103. Li, T.; Kon, N.; Jiang, L.; Tan, M.; Ludwig, T.; Zhao, Y.; Baer, R.; Gu, W. Tumor suppression in the absence of p53-mediated cell-cycle arrest, apoptosis, and senescence. Cell 2012, 149, 1269-1283. [CrossRef] [PubMed]

104. Pavlova, N.N.; Thompson, C.B. The emerging hallmarks of cancer metabolism. Cell Metab. 2016, 23, $27-47$. [CrossRef] [PubMed]

105. Martinez-Outschoorn, U.E.; Peiris-Pages, M.; Pestell, R.G.; Sotgia, F.; Lisanti, M.P. Cancer metabolism: A therapeutic perspective. Nat. Rev. Clin. Oncol. 2016, 14, 11. [CrossRef] [PubMed] 
106. Hsu, P.P.; Sabatini, D.M. Cancer cell metabolism: Warburg and beyond. Cell 2008, 134, 703-707. [CrossRef] [PubMed]

107. Salazar-Roa, M.; Malumbres, M. Fueling the cell division cycle. Trends Cell Biol. 2017, 27, 69-81. [CrossRef] [PubMed]

108. Williams, G.H.; Stoeber, K. The cell cycle and cancer. J. Pathol. 2012, 226, 352-364. [CrossRef] [PubMed]

109. Koppenol, W.H.; Bounds, P.L.; Dang, C.V. Otto warburg's contributions to current concepts of cancer metabolism. Nat. Rev. Cancer 2011, 11, 325-337. [CrossRef] [PubMed]

110. Vander Heiden, M.G.; Cantley, L.C.; Thompson, C.B. Understanding the warburg effect: The metabolic requirements of cell proliferation. Science 2009, 324, 1029-1033. [CrossRef] [PubMed]

111. Hay, N. Reprogramming glucose metabolism in cancer: Can it be exploited for cancer therapy? Nat. Rev. Cancer 2016, 16, 635-649. [CrossRef] [PubMed]

112. Szablewski, L. Expression of glucose transporters in cancers. Biochim. Biophys. Acta Rev. Cancer 2013, 1835, 164-169. [CrossRef] [PubMed]

113. Altman, B.J.; Stine, Z.E.; Dang, C.V. From Krebs to clinic: Glutamine metabolism to cancer therapy. Nat. Rev. Cancer 2016, 16, 619-634. [CrossRef] [PubMed]

114. Beloribi-Djefaflia, S.; Vasseur, S.; Guillaumond, F. Lipid metabolic reprogramming in cancer cells. Oncogenesis 2016, 5, e189. [CrossRef] [PubMed]

115. Currie, E.; Schulze, A.; Zechner, R.; Walther, T.C.; Farese, R.V., Jr. Cellular fatty acid metabolism and cancer. Cell Metab. 2013, 18, 153-161. [CrossRef] [PubMed]

116. Warburg, O. The metabolism of carcinoma cells. J. Cancer Res. 1925, 9, 148-163. [CrossRef]

117. Petros, J.A.; Baumann, A.K.; Ruiz-Pesini, E.; Amin, M.B.; Sun, C.Q.; Hall, J.; Lim, S.; Issa, M.M.; Flanders, W.D.; Hosseini, S.H.; et al. Mtdna mutations increase tumorigenicity in prostate cancer. Proc. Natl. Acad. Sci. USA 2005, 102, 719-724. [CrossRef] [PubMed]

118. Zhou, S.; Kachhap, S.; Sun, W.; Wu, G.; Chuang, A.; Poeta, L.; Grumbine, L.; Mithani, S.K.; Chatterjee, A.; Koch, W.; et al. Frequency and phenotypic implications of mitochondrial DNA mutations in human squamous cell cancers of the head and neck. Proc. Natl. Acad. Sci. USA 2007, 104, 7540-7545. [CrossRef] [PubMed]

119. Parsons, D.W.; Jones, S.; Zhang, X.; Lin, J.C.; Leary, R.J.; Angenendt, P.; Mankoo, P.; Carter, H.; Siu, I.M.; Gallia, G.L.; et al. An integrated genomic analysis of human glioblastoma multiforme. Science 2008, 321, 1807-1812. [CrossRef] [PubMed]

120. Bayley, J.P.; Devilee, P. Warburg tumours and the mechanisms of mitochondrial tumour suppressor genes. Barking up the right tree? Curr. Opin. Genet. Dev. 2010, 20, 324-329. [CrossRef] [PubMed]

121. Burk, D.; Schade, A.L. On respiratory impairment in cancer cells. Science 1956, 124, 270-272. [PubMed]

122. Warburg, O. On respiratory impairment in cancer cells. Science 1956, 124, 269-270. [PubMed]

123. Weinhouse, S. On respiratory impairment in cancer cells. Science 1956, 124, 267-269. [CrossRef] [PubMed]

124. Weinhouse, S.; Millington, R.H.; Wenner, C.E. Metabolism of neoplastic tissue. I. The oxidation of carbohydrate and fatty acids in transplanted tumors. Cancer Res. 1951, 11, 845-850. [PubMed]

125. Senyilmaz, D.; Teleman, A.A. Chicken or the egg: Warburg effect and mitochondrial dysfunction. F1000Prime Rep. 2015, 7, 41. [CrossRef] [PubMed]

126. Vega-Naredo, I.; Loureiro, R.; Mesquita, K.A.; Barbosa, I.A.; Tavares, L.C.; Branco, A.F.; Erickson, J.R.; Holy, J.; Perkins, E.L.; Carvalho, R.A.; et al. Mitochondrial metabolism directs stemness and differentiation in p19 embryonal carcinoma stem cells. Cell Death Differ. 2014, 21, 1560-1574. [CrossRef] [PubMed]

127. Wallace, D.C. Mitochondria and cancer. Nat. Rev. Cancer 2012, 12, 685-698. [CrossRef] [PubMed]

128. Penkert, J.; Ripperger, T.; Schieck, M.; Schlegelberger, B.; Steinemann, D.; Illig, T. On metabolic reprogramming and tumor biology: A comprehensive survey of metabolism in breast cancer. Oncotarget 2016, 7, 67626-67649. [CrossRef] [PubMed]

129. Boroughs, L.K.; DeBerardinis, R.J. Metabolic pathways promoting cancer cell survival and growth. Nat. Cell Biol. 2015, 17, 351-359. [CrossRef] [PubMed]

130. Levine, A.J.; Puzio-Kuter, A.M. The control of the metabolic switch in cancers by oncogenes and tumor suppressor genes. Science 2010, 330, 1340. [CrossRef] [PubMed]

131. Iurlaro, R.; Leon-Annicchiarico, C.L.; Munoz-Pinedo, C. Regulation of cancer metabolism by oncogenes and tumor suppressors. Methods Enzymol. 2014, 542, 59-80. [PubMed] 
132. Jones, R.G.; Thompson, C.B. Tumor suppressors and cell metabolism: A recipe for cancer growth. Genes Dev. 2009, 23, 537-548. [CrossRef] [PubMed]

133. Madan, E.; Gogna, R.; Bhatt, M.; Pati, U.; Kuppusamy, P.; Mahdi, A.A. Regulation of glucose metabolism by p53: Emerging new roles for the tumor suppressor. Oncotarget 2011, 2, 948-957. [CrossRef] [PubMed]

134. Hu, W.; Zhang, C.; Wu, R.; Sun, Y.; Levine, A.; Feng, Z. Glutaminase 2, a novel p53 target gene regulating energy metabolism and antioxidant function. Proc. Natl. Acad. Sci. USA 2010, 107, 7455-7460. [CrossRef] [PubMed]

135. Mathupala, S.P.; Heese, C.; Pedersen, P.L. Glucose catabolism in cancer cells. The type ii hexokinase promoter contains functionally active response elements for the tumor suppressor p53. J. Biol. Chem. 1997, 272, 22776-22780. [CrossRef] [PubMed]

136. Ruiz-Lozano, P.; Hixon, M.L.; Wagner, M.W.; Flores, A.I.; Ikawa, S.; Baldwin, A.S., Jr.; Chien, K.R.; Gualberto, A. P53 is a transcriptional activator of the muscle-specific phosphoglycerate mutase gene and contributes in vivo to the control of its cardiac expression. Cell Growth Differ. 1999, 10, 295-306. [PubMed]

137. Maddocks, O.D.; Berkers, C.R.; Mason, S.M.; Zheng, L.; Blyth, K.; Gottlieb, E.; Vousden, K.H. Serine starvation induces stress and p53-dependent metabolic remodelling in cancer cells. Nature 2013, 493, 542-546. [CrossRef] [PubMed]

138. Westermann, B. Bioenergetic role of mitochondrial fusion and fission. Biochim. Biophys. Acta Bioenerg. 2012, 1817, 1833-1838. [CrossRef] [PubMed]

139. Westermann, B. Mitochondrial fusion and fission in cell life and death. Nat. Rev. Mol. Cell Biol. 2010, 11, 872-884. [CrossRef] [PubMed]

140. Wai, T.; Langer, T. Mitochondrial dynamics and metabolic regulation. Trends Endocrinol. Metab. 2016, 27, 105-117. [CrossRef] [PubMed]

141. Youle, R.J.; van der Bliek, A.M. Mitochondrial fission, fusion, and stress. Science 2012, 337, $1062-1065$. [CrossRef] [PubMed]

142. Saleem, A.; Adhihetty, P.J.; Hood, D.A. Role of p53 in mitochondrial biogenesis and apoptosis in skeletal muscle. Physiol. Genom. 2009, 37, 58-66. [CrossRef] [PubMed]

143. Zamponi, N.; Zamponi, E.; Cannas, S.A.; Billoni, O.V.; Helguera, P.R.; Chialvo, D.R. Mitochondrial network complexity emerges from fission/fusion dynamics. Sci. Rep. 2018, 8, 363. [CrossRef] [PubMed]

144. Seo, A.Y.; Joseph, A.M.; Dutta, D.; Hwang, J.C.; Aris, J.P.; Leeuwenburgh, C. New insights into the role of mitochondria in aging: Mitochondrial dynamics and more. J. Cell Sci. 2010, 123, 2533-2542. [CrossRef] [PubMed]

145. Bourdon, J.C.; Fernandes, K.; Murray-Zmijewski, F.; Liu, G.; Diot, A.; Xirodimas, D.P.; Saville, M.K.; Lane, D.P. p53 isoforms can regulate p53 transcriptional activity. Genes Dev. 2005, 19, 2122-2137. [CrossRef] [PubMed]

146. Avery-Kiejda, K.A.; Morten, B.; Wong-Brown, M.W.; Mathe, A.; Scott, R.J. The relative mrna expression of p53 isoforms in breast cancer is associated with clinical features and outcome. Carcinogenesis 2014, 35, 586-596. [CrossRef] [PubMed]

147. Romano, R.A.; Smalley, K.; Magraw, C.; Serna, V.A.; Kurita, T.; Raghavan, S.; Sinha, S. Deltanp63 knockout mice reveal its indispensable role as a master regulator of epithelial development and differentiation. Development 2012, 139, 772-782. [CrossRef] [PubMed]

148. Lin, Y.L.; Sengupta, S.; Gurdziel, K.; Bell, G.W.; Jacks, T.; Flores, E.R. P63 and p73 transcriptionally regulate genes involved in DNA repair. PLoS Genet. 2009, 5, e1000680. [CrossRef] [PubMed]

149. Moll, U.M.; Slade, N. p63 and p73: Roles in development and tumor formation. Mol. Cancer Res. 2004, 2, 371-386. [PubMed]

150. Napoli, M.; Flores, E.R. The p53 family orchestrates the regulation of metabolism: Physiological regulation and implications for cancer therapy. Br. J. Cancer 2017, 116, 149-155. [CrossRef] [PubMed]

151. Levine, A.J.; Tomasini, R.; McKeon, F.D.; Mak, T.W.; Melino, G. The p53 family: Guardians of maternal reproduction. Nat. Rev. Mol. Cell Biol. 2011, 12, 259-265. [CrossRef] [PubMed]

152. Du, W.; Jiang, P.; Mancuso, A.; Stonestrom, A.; Brewer, M.D.; Minn, A.J.; Mak, T.W.; Wu, M.; Yang, X. Tap73 enhances the pentose phosphate pathway and supports cell proliferation. Nat. Cell Biol. 2013, 15, 991-1000. [CrossRef] [PubMed]

153. Venkatanarayan, A.; Raulji, P.; Norton, W.; Chakravarti, D.; Coarfa, C.; Su, X.; Sandur, S.K.; Ramirez, M.S.; Lee, J.; Kingsley, C.V.; et al. IAPP-driven metabolic reprogramming induces regression of p53-deficient tumours in vivo. Nature 2015, 517, 626-630. [CrossRef] [PubMed] 
154. Giacobbe, A.; Bongiorno-Borbone, L.; Bernassola, F.; Terrinoni, A.; Markert, E.K.; Levine, A.J.; Feng, Z.; Agostini, M.; Zolla, L.; Agro, A.F.; et al. p63 regulates glutaminase 2 expression. Cell Cycle 2013, 12, 1395-1405. [PubMed]

155. Rufini, A.; Niklison-Chirou, M.V.; Inoue, S.; Tomasini, R.; Harris, I.S.; Marino, A.; Federici, M.; Dinsdale, D.; Knight, R.A.; Melino, G.; et al. Tap73 depletion accelerates aging through metabolic dysregulation. Genes Dev. 2012, 26, 2009-2014. [CrossRef] [PubMed]

156. Harrelson, J.P.; Lee, M.W. Expanding the view of breast cancer metabolism: Promising molecular targets and therapeutic opportunities. Pharmacol. Ther. 2016, 167, 60-73. [CrossRef] [PubMed]

157. Ogrodzinski, M.P.; Bernard, J.J.; Lunt, S.Y. Deciphering metabolic rewiring in breast cancer subtypes. Transl. Res. 2017, 189, 105-122. [CrossRef] [PubMed]

158. Won, K.Y.; Lim, S.J.; Kim, G.Y.; Kim, Y.W.; Han, S.A.; Song, J.Y.; Lee, D.K. Regulatory role of p53 in cancer metabolism via SCO2 and tigar in human breast cancer. Hum. Pathol. 2012, 43, 221-228. [CrossRef] [PubMed]

159. Hatoum, D.; McGowan, E.M. Recent advances in the use of metformin: Can treating diabetes prevent breast cancer? BioMed Res. Int. 2015, 2015, 548436. [CrossRef] [PubMed]

160. Wade, M.; Li, Y.-C.; Wahl, G.M. MDM2, MDMX and p53 in oncogenesis and cancer therapy. Nat. Rev. Cancer 2013, 13, 83-96. [CrossRef] [PubMed]

161. Yang, Y.; Ludwig, R.L.; Jensen, J.P.; Pierre, S.A.; Medaglia, M.V.; Davydov, I.V.; Safiran, Y.J.; Oberoi, P.; Kenten, J.H.; Phillips, A.C.; et al. Small molecule inhibitors of HDM2 ubiquitin ligase activity stabilize and activate p53 in cells. Cancer Cell 2005, 7, 547-559. [CrossRef] [PubMed]

162. Burgess, A.; Chia, K.M.; Haupt, S.; Thomas, D.; Haupt, Y.; Lim, E. Clinical overview of MDM2/X-targeted therapies. Front. Oncol. 2016, 6, 7. [CrossRef] [PubMed]

163. Crane, E.K.; Kwan, S.Y.; Izaguirre, D.I.; Tsang, Y.T.; Mullany, L.K.; Zu, Z.; Richards, J.S.; Gershenson, D.M.; Wong, K.K. Nutlin-3a: A potential therapeutic opportunity for TP53 wild-type ovarian carcinomas. PLoS ONE 2015, 10, e0135101. [CrossRef] [PubMed]

164. Das, M.; Dilnawaz, F.; Sahoo, S.K. Targeted nutlin-3a loaded nanoparticles inhibiting p53-MDM2 interaction: Novel strategy for breast cancer therapy. Nanomedicine 2011, 6, 489-507. [CrossRef] [PubMed]

165. Chene, P. Inhibiting the p53-MDM2 interaction: An important target for cancer therapy. Nat. Rev. Cancer 2003, 3, 102-109. [CrossRef] [PubMed]

166. Agrawal, A.; Yang, J.; Murphy, R.F.; Agrawal, D.K. Regulation of the p14arf-MDM2-p53 pathway: An overview in breast cancer. Exp. Mol. Pathol. 2006, 81, 115-122. [CrossRef] [PubMed]

167. Llanos, S.; Clark, P.A.; Rowe, J.; Peters, G. Stabilization of p53 by p14arf without relocation of MDM2 to the nucleolus. Nat. Cell Biol. 2001, 3, 445-452. [CrossRef] [PubMed]

168. Bates, S.; Phillips, A.C.; Clark, P.A.; Stott, F.; Peters, G.; Ludwig, R.L.; Vousden, K.H. P14arf links the tumour suppressors RB and p53. Nature 1998, 395, 124-125. [CrossRef] [PubMed]

169. Yi, Y.; Shepard, A.; Kittrell, F.; Mulac-Jericevic, B.; Medina, D.; Said, T.K. P19arf determines the balance between normal cell proliferation rate and apoptosis during mammary gland development. Mol. Biol. Cell 2004, 15, 2302-2311. [CrossRef] [PubMed]

170. Kuperwasser, C.; Pinkas, J.; Hurlbut, G.D.; Naber, S.P.; Jerry, D.J. Cytoplasmic sequestration and functional repression of p53 in the mammary epithelium is reversed by hormonal treatment. Cancer Res. 2000, 60, 2723-2729. [PubMed]

171. Tsubura, A.; Uehara, N.; Matsuoka, Y.; Yoshizawa, K.; Yuri, T. Estrogen and progesterone treatment mimicking pregnancy for protection from breast cancer. In Vivo 2008, 22, 191-201. [PubMed]

172. Harland, M.; Taylor, C.F.; Chambers, P.A.; Kukalizch, K.; Randerson-Moor, J.A.; Gruis, N.A.; de Snoo, F.A.; ter Huurne, J.A.; Goldstein, A.M.; Tucker, M.A.; et al. A mutation hotspot at the p14arf splice site. Oncogene 2005, 24, 4604-4608. [CrossRef] [PubMed]

173. Burri, N.; Shaw, P.; Bouzourene, H.; Sordat, I.; Sordat, B.; Gillet, M.; Schorderet, D.; Bosman, F.T.; Chaubert, P. Methylation silencing and mutations of the p14arf and p16ink4a genes in colon cancer. Lab. Investig. 2001, 81, 217-229. [CrossRef] [PubMed]

174. Huang, Y.; Tyler, T.; Saadatmandi, N.; Lee, C.; Borgstrom, P.; Gjerset, R.A. Enhanced tumor suppression by a p14arf/p53 bicistronic adenovirus through increased p53 protein translation and stability. Cancer Res. 2003, 63, 3646-3653. [PubMed]

175. Bandorowicz-Pikula, J.; Wos, M.; Sekrecka-Belniak, A.; Pikula, S. Annexins in mitochondria. Postepy Biochem. 2016, 62, 216-223. [PubMed] 
176. Chlystun, M.; Campanella, M.; Law, A.L.; Duchen, M.R.; Fatimathas, L.; Levine, T.P.; Gerke, V.; Moss, S.E. Regulation of mitochondrial morphogenesis by annexin a6. PLoS ONE 2013, 8, e53774. [CrossRef] [PubMed]

177. Bailey, S.T.; Shin, H.; Westerling, T.; Liu, X.S.; Brown, M. Estrogen receptor prevents p53-dependent apoptosis in breast cancer. Proc. Natl. Acad. Sci. USA 2012, 109, 18060-18065. [CrossRef] [PubMed]

178. Liu, W.; Konduri, S.D.; Bansal, S.; Nayak, B.K.; Rajasekaran, S.A.; Karuppayil, S.M.; Rajasekaran, A.K.; Das, G.M. Estrogen receptor- $\alpha$ binds p53 tumor suppressor protein directly and represses its function. J. Biol. Chem. 2006, 281, 9837-9840. [CrossRef] [PubMed]

179. Konduri, S.D.; Medisetty, R.; Liu, W.; Kaipparettu, B.A.; Srivastava, P.; Brauch, H.; Fritz, P.; Swetzig, W.M.; Gardner, A.E.; Khan, S.A.; et al. Mechanisms of estrogen receptor antagonism toward p53 and its implications in breast cancer therapeutic response and stem cell regulation. Proc. Natl. Acad. Sci. USA 2010, 107, 15081-15086. [CrossRef] [PubMed]

180. Osborne, C.K. Steroid hormone receptors in breast cancer management. Breast Cancer Res. Treat. 1998, 51, 227-238. [CrossRef] [PubMed]

181. Salvatori, L.; Pallante, P.; Ravenna, L.; Chinzari, P.; Frati, L.; Russo, M.A.; Petrangeli, E. Oestrogens and selective oestrogen receptor (ER) modulators regulate EGF receptor gene expression through human er $[\alpha]$ and $[\beta]$ subtypes via a sp1 site. Oncogene 0000, 22, 4875-4881. [CrossRef] [PubMed]

182. Jordan, V.C. Chemoprevention of breast cancer with selective oestrogen-receptor modulators. Nat. Rev. Cancer 2007, 7, 46-53. [CrossRef] [PubMed]

183. Islam, R.A.; Hossain, S.; Chowdhury, E.H. Potential therapeutic targets in energy metabolism pathways of breast cancer. Curr. Cancer Drug Targets 2017, 17, 707-721. [CrossRef] [PubMed]

184. Lee, I.M. Physical activity and cancer prevention-data from epidemiologic studies. Med. Sci. Sports Exerc. 2003, 35, 1823-1827. [CrossRef] [PubMed]

185. Holloszy, J.O. Biochemical adaptations in muscle. Effects of exercise on mitochondrial oxygen uptake and respiratory enzyme activity in skeletal muscle. J. Biol. Chem. 1967, 242, 2278-2282. [PubMed]

186. San-Millan, I.; Brooks, G.A. Reexamining cancer metabolism: Lactate production for carcinogenesis could be the purpose and explanation of the warburg effect. Carcinogenesis 2017, 38, 119-133. [CrossRef] [PubMed]

187. Turcotte, L.P.; Richter, E.A.; Kiens, B. Increased plasma FFA uptake and oxidation during prolonged exercise in trained vs. Untrained humans. Am. J. Physiol. 1992, 262, E791-E799. [CrossRef] [PubMed]

188. Bartlett, J.D.; Close, G.L.; Drust, B.; Morton, J.P. The emerging role of p53 in exercise metabolism. Sports Med. 2014, 44, 303-309. [CrossRef] [PubMed]

(C) 2018 by the authors. Licensee MDPI, Basel, Switzerland. This article is an open access article distributed under the terms and conditions of the Creative Commons Attribution (CC BY) license (http://creativecommons.org/licenses/by/4.0/). 